\title{
PURE IDEOLOGY: THE "OWNERSHIP SPLIT" OF POWER COMPANIES IN THE 1998 ELECTRICITY REFORMS
}

\author{
Daniel Kalderimis*
}

In April 1998 the New Zealand Government announced a reform package for the electricity industry. This package was designed to create the competition promised since deregulation first began in 1987. The 1998 reforms had two main aspects: first, the split of the Electricity Corporation of New Zealand (ECNZ), New Zealand's dominant state-owned enterprise (SOE) generator, into three competitive units; second, a rule business (the ownership split) that local power companies could not own both a lines business (the local distribution wires) and a generation or retail.

The ownership split caused a revolution in the industry. Effectively, small community-owned companies were forced to sell their retail and generation businesses to larger companies or to the State, in the form of the ECNZ "babies". The Government believed that the ownership split would facilitate retail competition and deliver lower domestic power prices. This article asks whether the Government was right - whether the ownership split was necessary, or able, to reduce domestic power prices. It concludes that the ownership split was a staggering mistake. The Government's reasoning was based on inconclusive evidence, inadequate research, and contained major logical flaws. The Government rejected unanimous policy advice warning against the split. Since the split, average domestic power prices have risen by almost four per cent. A major factor is the demise of community-owned supply companies which had offered unique advantages to consumers.

The root of this disaster was ideological bias. The Government did not understand the electricity industry but treated it as an abstract economic construct. This article documents the way in which ideology led the Government to wreak havoc on an industry in order to cure problems which did not exist.

Judge's Clerk, Court of Appeal. This article is an edited version of a paper submitted as part of the LLB(Hons) requirements in 1999. Following the change of government, the electricity industry was, on 3 February 2000, placed under review by a Ministerial Inquiry due to report in mid-July. 


\section{INTRODUCTION}

In April 1998, the New Zealand Government announced a reform package for the electricity industry, spearheaded by the Electricity Industry Reform Act 1998 (EIR Act). ${ }^{1}$ This package made several changes to the generation, distribution and retail sectors. ${ }^{2}$ The two most significant changes were effected by the EIR Act itself. The first was intended to increase generation competition by splitting the Electricity Corporation of New Zealand (ECNZ), New Zealand's dominant state-owned enterprise (SOE) generator, into three smaller SOEs. ${ }^{3}$ The second was intended to increase retail competition by forcing local electricity companies to sell either their lines or their supply (generation or retail) businesses by 2004 (the ownership split). ${ }^{4}$

The industry reaction to the reforms was swift. Between July 1998 and April 1999, New Zealand witnessed an incredible frenzy of activity. Every electricity company in the country was suddenly in a hurry to sell down or buy up or both. Many companies changed their name to rebrand themselves for the new era. Some kept the same name but changed their business or were taken over by a competitor. Government officials were left surprised everything had happened so fast; consumers were simply left confused. When the dust had settled, New Zealand had gone from having two major generators and 35 electricity lines/retail companies, to six major generation/retail companies and 31 lines companies. Almost overnight, New Zealand had a new electricity sector.

Of all the reform measures, that responsible for this dramatic revolution was clearly the ownership split. The selling frenzy occurred because all electricity companies had to decide to either sell one business outright or chose a less viable compliance option by April 1999. 5 The official reason for the ownership spilt was a desire for increased domestic retail

1 Hon W Peters, Rt Hon B Birch, Hon M Bradford "A Better Deal for Electricity Consumers" Media Release, 7 April 1998 ["A Better Deal for Electricity Consumers"].

2 "A Better Deal for Electricity Consumers" above n 1, 1-2. The only sector not affected was transmission. See page 257 below for a brief description of the different industry sectors.

3 In 1998 ECNZ owned 59 per cent of New Zealand's installed capacity: Contact Energy "Investment Statement" 31 March 1999, 15. In 1997, ECNZ accounted for 70 per cent of total electricity sales: Cabinet Committee on Industry and Environment "Electricity Reforms: Paper 2: Analysis of Problems" 1 December 1997, CIE (97) 193, 3 ["Cabinet Committee Two"]. For the abbreviations of Government policy documents cited in this paper, see Appendix Three.

4 A lines business is any business (apart from the national grid) that conveys more than $2.5 \mathrm{GWh}$ per annum of electricity by line: EIR Act, s 4 . It is the distribution side of the industry (the terms "lines" and "distribution" are used synonymously in this paper). A supply business is any business that sells or generates electricity: EIR Act, s 5; it is the production and retail side of the industry.

5 For details of the options under the EIR Act, see below Part IV. 
competition leading to lower domestic power prices. ${ }^{6}$ The ownership split and its effect on domestic electricity consumers is therefore the subject of this paper. The two questions this paper asks is whether total separation was necessary for real domestic competition; and whether the new industry the split created is really better than the one it destroyed.

The paper concludes that the answer to both questions is an emphatic "No". This conclusion is not possible only in hindsight, but was obvious back in April 1998. The decision to split power companies was based on inadequate research, rejected key advice, and was logically flawed. In practice, the split achieved nothing. The retail competition sought has come about for quite different reasons - namely new technology and the four SOE generators moving into the retail market. The only legacy of the split is the significant damage it has caused. In particular this damage has been borne by customers of the most popular form of electricity company - a community-owned company - which operated mainly in provincial and rural regions. ${ }^{7}$

The reasoning behind the ownership split reveals the triumph of pure ideology over common sense. Quite clearly, the government did not understand the complexities of a unique industry. This paper argues, using international comparisons, that ownership separation was regulation straight from an elementary level economics textbook.

\section{THE OWNERSHIP SPLIT IN CONTEXT}

In order to understand the policy problem the ownership split was intended to remedy, it is necessary to understand some background to the 1998 reforms. Generally, it should be noted that an electricity industry has four distinct components: generation; long distance transmission via the high-voltage national grid; distribution via local lines networks; and retail to consumers.

\section{A 1888 -1987: From Fledgling Industry to Effective Monopoly}

As with most new industries, electricity in New Zealand was initially the province of pioneering entrepreneurs. New Zealand's first public electricity supply began just over a century ago in Reefton on 4 August $1888 .^{8}$ Following this, a number of private individuals

6 "A Better Deal for Electricity Consumers" above n 1, 1; Hon W Peters, Hon M Bradford "Electricity Distribution and Retail Reforms" Media Release, 7 April 1998, 1 ["Electricity Distribution and Retail Reforms"].

7 In 1998 there were 35 electricity companies, 22 of which were wholly-community owned: Carolyn Wylie New Zealand Electricity Directory 1998 (Chameleon Enterprises, Wellington, 1998) 19.

8 This occurred when a local plumber connected residents to a generator, giving them electric lighting: Neil Rennie Power to the People: One Hundred Years of Electricity Supply in New Zealand (Electricity Supply Association of New Zealand, Wellington, 1989) 13. 
or companies set up generators - either for their own use or for public supply. ${ }^{9}$ The government did not take long to recognise the value of this new resource.

By 1920, the Government had enacted the trilogy of statutes which defined the shape of the industry for most of this century: the State Supply of Electricity Act 1917; the Electricpower Boards Act 1918; and the Municipal Corporations Act 1920. The first of these gave the government the sole right to acquire, construct or maintain any generation scheme. ${ }^{10}$ The second allowed New Zealand to be carved into separate electric power districts for which a specific body, named an electric power board, was authorised to supply electricity to end users. ${ }^{11}$ An electric power board was a locally elected committee. Power boards were prohibited from purchasing or building generation schemes without government permission. ${ }^{12}$ Finally the Municipal Corporations Act permitted local councils to supply electricity to their constituents. ${ }^{13}$

The system these statutes created was consolidated in the Electricity Act 1968 and essentially remained in place until 1987. The government had a statutory monopoly on generation but did not supply electricity directly to consumers. ${ }^{14}$ This was done by either power boards or local authorities, collectively known as Electricity Supply Authorities (ESAs), which brought electricity in bulk from the State. ${ }^{15}$ ESAs could not compete with

9 For instance, Wellington's first public lighting was supplied in 1889 by the Gulcher Electric Light and Power Co: Rennie, above n 8, 34-35.

10 State Supply of Electricity Act 1917, 8 Geo V 111, s 3(1).

11 Electric-power Boards Act 1918, 9 Geo V 35, ss 3(1) and 4(1). This Act was soon repealed and replaced by the very similar Electric-power Boards Act 1925, 16 Geo V 316 (see s 129 and the schedule). The corresponding sections in the 1925 Act are ss 3(1) and 9(1). All further references are to the 1925 Act.

12 Electric-power Boards Act 1925, 16 Geo V 316, s 76(1). Even with permission, the government could, by giving 12 months notice, purchase the works for itself: Electric-power Boards Act 1925, 16 Geo V 316, s 95.

13 Municipal Corporations Act 1920, 11 Geo V 283, s 281(1).

14 Electricity Act 1968, ss 25 and 26. In practice, it took the government some time to acquire a genuine generation monopoly. For much of the 1930s, the only way for a community to get electricity was to build its own generation plant. However as the state hydro system grew, such schemes became less significant or were purchased by the government: Rennie, above n 8, 108.

15 With such a large and fledgling industry, there were obviously exceptions. For instance the government took over the operations of the Southland Electric Power Board in 1936. Similarly, many ESAs were allowed to build, and continued to own, generation plants. This happened in particularly in Northland, Nelson/Marlborough, Central Otago and the West Coast: Rennie, above $\mathrm{n} 8,108$. 
each other but held "area franchises": licences authorising distribution and retail to a specific area. ${ }^{16}$

By the mid-1980s New Zealand's electricity infrastructure was mostly in place. Legally, the system was made up of two separate monopolies. The State owned and had built most generation plants and the national grid. However local ESAs developed and operated the distribution networks and supplied customers with electricity. The overall result - 90 per cent of customers able to receive electricity ${ }^{17}$ - was clearly a "partnership" between the State and local communities.

\section{B 1987 -1996: Restructuring an Industry}

In the 1980s the government department responsible for electricity was the New Zealand Electricity Division (NZED) of the Ministry of Energy. At this time, NZED generated almost all of New Zealand's electricity. On 1 April 1987, NZED became ECNZ, New Zealand's largest SOE. ${ }^{18}$ A few months later the Government removed the requirement for state approval to set up hydro generation schemes and allowed ESAs to generate electricity themselves and to buy from persons other than the state. ${ }^{19}$ The state's statutory monopoly on generation was gone.

Following this, two important pieces of legislation were passed: the Electricity Act 1992 and the Energy Companies Act 1992. The former Act repealed the Electricity Act 1968 and thus removed the need for area specific licences in order to supply electricity. ${ }^{20}$ There was no longer an obligation to sell electricity to particular customers, although lines had to be maintained until 2013. ${ }^{21}$ By 1994, full retail competition was permitted. In accordance with the principles of light-handed regulation, the Act also provided for the making of information disclosure regulations. ${ }^{22}$

16 Electricity Act 1968, s 20.

17 Rennie, above n 8, 245.

18 State-Owned Enterprises Act 1986, s 2 and First Schedule.

19 Electricity Amendment Act 1987. This Act, through ss 3(k) and (l) repealed ss 25 and 26 of the Electricity Act 1968 (see above n 14).

20 It did this in two stages. Small consumers (persons who used less than 0.5 GWh of electricity) became fully contestable from 1 April 1993; larger consumers became contestable one year later.

21 Electricity Act 1992, ss 62(2) and (6).

22 See the definition of "light-handed regulation" in Ministry of Commerce "Background Material and Options for Increasing Efficiency in Electricity Distribution and Retailing" 4 December 1997, 8 ["Commerce Four"]. 
The Energy Companies Act 1992 forced ESAs to incorporate. Every ESA had to submit for government approval an "establishment plan" detailing the method by which they would transfer their electricity (or gas) undertaking to a newly set up energy company (EC). This plan would include all relevant details, such as draft articles of association, the time at which the transfer would take place, what would happen to existing employees and, most importantly, a share allocation plan. ${ }^{23}$

The share allocation plan was not easy to formulate. It was unclear exactly who owned ESAs and their assets - assets that had been locally built up over most of this century. The Government had intended the share issue to lead to widespread privatisation. ${ }^{24}$ However in the end, the most popular option was an hybrid company/trust model. Under this model the shares in the new energy company would be held by a trust whose beneficiaries were the "community" - usually electricity consumers at the time. Ultimately 21 of 44 energy companies elected to be wholly owned by community or consumer trusts and 10 elected partial trust-ownership. One was a co-operative company (owned by the community), nine were owned by local councils; and only three were investor-owned. ${ }^{25}$

Reform continued. In 1988 the Government had reorganised ECNZ so that the national grid was run by a subsidiary company, named Transpower. On 1 July 1994 the government made Transpower a separate SOE. ${ }^{26}$ From this date, ECNZ was solely a generator. The decision thus separated the part of ECNZ that was able to compete from the natural monopoly part which was not, providing equal access to the national grid.

In February 1996 a new SOE, Contact Energy, was split from ECNZ. ${ }^{27}$ It was to be a significant generator owning eight power stations. Overall, it represented 22 per cent of New Zealand's electricity production. ${ }^{28}$ Until 1998, both ECNZ and Contact were forbidden to enter into the retail market through directives in their Statements of

23 Energy Companies Act 1992, s 18. The Minister of Energy could direct the content of the plan: s 18(2)(i).

24 See Office of the Minister of Energy "Electricity Industry Reform" 10 December 1990, paras 34 - 37.

25 Carolyn Wylie New Zealand Electricity Directory 1993 (Chameleon Enterprises, Wellington, 1993) 13

26 State-Owned Enterprises Order 1994 (SR 1994/87).

27 State-Owned Enterprises Order 1995 (SR 1995/250).

28 John E Martin (ed) People, Politics and Power Stations (2 ed, ECNZ, Wellington, 1998) 323. It now represents 28 per cent: "Investment Statement" above n 3, 15. 
Corporate Intent. ${ }^{29}$ Incidentally, Contact was privatised in April 1999 following the collapse of the National-New Zealand First Coalition Government, whose core agreement had prohibited the sale of certain strategic assets, including Contact, ECNZ and Transpower. ${ }^{30}$

Finally, in October 1996, a wholesale market for electricity was established by the industry. A wholesale electricity market is basically a multilateral contract whereby market participants (generators, purchasers and traders) agree to a methodology for determining the price and dispatch of electricity. The market had been in the pipeline since 1992 and there had been many different suggestions. The market ultimately established was not compulsory and was owned by an entity independent of both the government and industry participants. It is an "ex-post" market in that prices are not known in advance but are based on the offers of generators feeding load into the pool. The highest cost electricity necessary to meet demand is determined every half hour, setting the "spot" price for that half hour, and the lowest-bid electricity is then sold first. ${ }^{31}$ The market is self-regulating, having established a Market Surveillance Committee for this purpose.

\section{1996 -1998: Structure in Place but Results Slow in Coming}

By 1996, New Zealand had one of the most deregulated electricity industries in the world. The transmission grid was owned by a separate entity. Competitive generation was not only permitted but actively encouraged by the Government. To this very end, Contact had been created and a wholesale market was in operation. And since 1994 full retail competition was permitted. In short, anyone could produce electricity, gain access to the national grid and sell to any consumer.

However the obstinate status quo remained. In practice, competition in generation was tame, competition for industrial consumers was moderate, and competition for most

29 For Contact see Statements of Corporate Intent for 1996 to 1998. Compare 1999: "Contact's core business is primarily the production and sale of energy" (emphasis added). For ECNZ see Statements of Corporate Intent for 1995 to 1998. Compare 1999: "The Corporation's business is primarily the generation and marketing of electricity". ECNZ was also placed under special restrictions relating to pricing structures and building new generators: see Memorandum of Understanding between ECNZ and the Crown, 8 June 1995, in the New Zealand Gazette, 23 February 1996, No 16, 525.

30 The sale was comprised of a 60 per cent public share float and a 40 per cent "cornerstone" stake, sold to Edison Mission Energy Taupo Ltd, a subsidiary of the US based Edison Mission Energy. See State Owned Enterprises (Contact Energy) Amendment Act 1998.

31 It is called a spot price because every imbalance between the electricity contracted for and the electricity in fact used is treated as an instantaneous spot transaction. 
commercial and all domestic consumers was non-existent. ${ }^{32}$ As regards generation, ECNZ had market dominance and was able to manipulate both wholesale and hedge markets. ${ }^{33}$ On the retail side, competition was small and getting smaller. By 1997, it appeared that the proportion of the "contestable" industrial customers being supplied by competing retailers was between 3.3 per cent and 8.5 per cent and was shrinking. ${ }^{34}$

Domestic power prices rose 21 per cent in real terms between 1987 and $1997 .{ }^{35}$ Industrial prices fell seven per cent and commercial prices fell 26 per cent in real terms during this period. ${ }^{36}$ There were three good reasons for this disparity. The first was the removal of the historic cross-subsidy from commercial to domestic consumers; the second was the transition of ESAs from non-profit power boards to companies required to earn a commercial rate of return; ${ }^{37}$ and the third was the existence of competition for industrial customers. However, these caveats aside, the new system clearly was not working properly. While New Zealand had a more competitively oriented market than most in the world, consumers - especially domestic consumers - were still awaiting results.

\section{Problems identified}

In the lead-up to the Act, a number of problems were identified; some actual; some theoretical. Before discussing the decision to split integrated ECs, it is helpful to first highlight some of the major problems which the ownership split was not intended to solve.

32 The Commerce Commission estimated that competition was effectively limited to customers who consumed more than 0.5GWh per annum. Sixty-one per cent of total consumers used less than this and thus were effectively not contestable. See "Commerce Four" above n 22, 17.

33 A hedge contract is a contract whereby the buyer agrees to buy electricity at a fixed price, regardless of the spot price on the day. It is primarily a financial instrument and is used to "hedge" against the risks of variable spot prices.

34 The former figure (3.3 per cent - down from 4.6 per cent in 1996) is the proportion of electricity reconciled through the wholesale market. However as the market is not compulsory, electricity could still be sold competitively outside it. The Commerce Commission estimated the figure of 8.5 per cent (down from 9.9 per cent in 1996) overall: see "Commerce Four" above n 22, 16.

35 Official's Committee on Energy Policy (OCEP) "Electricity Distribution and Retail Sector Reform" (Briefing Paper) 24 October 1997, 2 ["OCEP Five"]. "Commercial" consists of trade, transport, communications and services. "Industrial" consists of primary industries, including manufacturing, electricity, gas, water and construction.

36 "OCEP Five" above n 35, 2.

37 Both factors are explicitly acknowledged in "Cabinet Committee Two" above n 3, 3; "Commerce Four" above n 22, 5 and 7; and Treasury "Regulatory Issues in the Electricity Distribution and Retail Sector" 28 August 1997, 4 ["Treasury One"]. 
First, the main problem in the generation sector was a lack of players. The market was a duopoly and ECNZ had clear market dominance. ${ }^{38}$ Purchasers had no real alternative but to buy from ECNZ at ECNZ-set prices - a problem that was not adequately addressed by Contact's market presence since 1996. ${ }^{39}$ ECNZ's incentives were to keep average wholesale prices up around the entry price to the market rather than strive to drive them down. ${ }^{40}$ As generation costs comprise roughly 45 per cent of an average power bill, higher than necessary generation charges were a genuine concern. ${ }^{41}$ This problem was addressed by dividing ECNZ into three smaller competitive chunks.

Secondly, in the retail and distribution sectors, the most obvious problems were the technological impediments to domestic competition. In order for different suppliers to compete, there had to be some system for reconciling whose electricity was travelling through which lines at which time. Essentially this required what are known as "time-ofuse" meters which measure levels of electricity consumption every half-hour (the same period as changes in the spot price), as opposed to more familiar meters which only measure consumption cumulatively. ${ }^{42}$ Large industrial customers have had time-of-use meters installed for years.

However such meters are expensive, costing around $\$ 300-\$ 400$ to install. ${ }^{43}$ Retail is notoriously the least profitable of the four electricity businesses. The net retail margin from an average domestic electricity customer is basically between three and six per cent of

38 This is acknowledged in "Cabinet Committee Two" above n 3, 6.

39 Market opinion largely viewed Contact as merely "following" ECNZ-set prices: see OCEP "Electricity Reforms: Summary of Submissions" 29 August 1997, Annex II ["OCEP Two"].

40 As an example, in 1996 and 1997 the cost-effective Huntly power station sacrificed volume to the older, less efficient New Plymouth power station in order to maintain overall ECNZ prices: ECNZ "Response to Electricity Industry Review" 11 December 1997, 7 ["Response to Review"] (officials' comment on ECNZ's submissions).

41 Gary Eng, Energy Analyst, Ministry of Commerce, 26 August 1999 (giving an informal estimate). The Community-Owned Companies Submission to the Commerce Committee (June 1998) para 4.1 ["Community Companies Submission"] estimated 50 per cent.

42 Electricity Market Company "Competition In the Retail Market: A Backgrounder" (Electricity Market Company, Wellington, February 1999) 1-2.

43 New Zealand Institute of Economic Research (NZIER) "Metering and Profiling: Competition for Small Electricity Consumers" September 1997, 3 ["Metering and Profiling"]. 
the total bill, ${ }^{44}$ or $\$ 50$ per customer per annum. ${ }^{45}$ Installing time-of-use meters across the board simply was not economic for ECs which would not easily recoup the expense with retail profit. ${ }^{46}$ Similarly, consumers would not easily recoup the cost of such meters by potential savings they could make from competition. ${ }^{47}$ This was the biggest barrier to retail competition identified by most government advisors. ${ }^{48}$ This problem was addressed by exhorting the industry to develop deemed profiling, which uses agreed statistical profiles to estimate the load share of individual customers. Profiling has been in use since 1 April 1999.

Residual problems of weak domestic retail competition were also addressed by allowing Contact and the three new SOE generators to enter the retail market for the first time.

Thirdly, there was a smaller but still significant problem related to the valuation methodology for lines businesses. The profits of a monopoly lines business are informally meant to be in line with the value of its asset base. However, there were concerns that under the prevailing system, ECs were able to artificially undervalue their assets and thus extract monopoly profits. This problem was addressed by the Ministry of Commerce introducing a new valuation handbook in May 1999. ${ }^{49}$

44 There is broad industry agreement that the average gross margin (from which all indirect and administrative costs must come) is about 10 per cent of the total bill: see "Cabinet Committee Two" above n 3, 10; "Metering and Profiling" above n 43, 2. The "Community Companies Submission" above $n$ 41, para 4.1 estimated the average net retail margin left over to be three per cent. It is widely acknowledged not to be higher than six per cent: interview with Alan Jenkins, CEO Electricity Networks Association, 3 August 1999.

45 Assessed at a net margin of five per cent. Figures based on the average New Zealand domestic consumer using $8000 \mathrm{kWh}$ (the consumption deemed to be average by the Energy Market Regulation Unit of the Ministry of Commerce) of energy a year at the 1998 overall average price of 12.54 cents per $\mathrm{kWh}$ (for the data source, see Appendix One).

46 "Cabinet Committee Two" above n 3, 6.

47 "Cabinet Committee Two" above n 3, 6.

48 See "Cabinet Committee Two" above n 3, 6; Ministry of Commerce "Magnitude of Regulatory Problems in Electricity Distribution and Retailing" 21 November 1997, 4 ["Commerce Three"]; OCEP "Electricity Distribution and Retail Reform: Policy Options" 18 February 1998, 3 ["OCEP Eight"]; Treasury "Competition Issues in the Electricity Industry" Memorandum to Senior Management Group, 9 October 1997, 12 ["Treasury Two"]; Commerce "NZIER Report: Metering and Profiling: Competition for Small Electricity Consumers" 3 October 1997, 3 ["Commerce Two"]; and "Metering and Profiling" above n 43, 2. See also OCEP "Electricity Reforms: Summary of Submissions" 29 August 1997, 4-5 ["OCEP Two"].

49 See Ministry of Commerce "Handbook for Optimised Deprival Valuation of System Fixed Assets of Electricity Line Businesses" (Ministry of Commerce, Wellington, 21 May 1999). 
Fourthly, there were too many ECs operating in small areas. This number steadily dropped following the 1987 reforms but was still too high. Greater efficiencies would be achieved through mergers or amalgamations. This problem was not directly addressed. It could be argued that it was indirectly targeted by some of the other measures such as the threatened price control and (in the retail industry) the ownership split. However it is fair to say that industry rationalisation was a hoped for side effect, rather than a primary aim, of the reform measures as a whole. In fact, since the 1998 reforms, the total number of electricity companies has increased.

\section{$D$ 1998: Specific Policy Problems Requiring Ownership Split}

The ownership split was introduced to cure the main problem in the distribution/retail side of the industry: a lack of domestic competition. As noted above, competition was in truth prevented by inadequate technology. Until deemed profiling was developed in 1999, there was no cost-effective ability to compete for low-value customers.

However the Government was also concerned about certain largely theoretical problems inherent in integrated lines/supply businesses. The basic concern is easy to state: ECs were composed of two (and sometimes three) related businesses: a lines business, which is a natural monopoly in that it would ordinarily be inefficient for a competitor to duplicate the local network; and a retail and sometimes a generation business, which are potentially competitive. The Government was concerned about the problems created by leaving both the natural monopoly and the potentially competitive businesses in a single entity. These problems are conveniently listed in a host of government discussion papers on this issue. Integrated lines/supply ECs are said to have incentives to: ${ }^{50}$

(1) charge monopoly rents for use of their lines;

(2) cross-subsidise costs of their retail or generation businesses with profits from their lines businesses, thus providing anti-competitively low-cost services or funding inefficient generation; and

(3) restrict competitor access to their lines.

50 See Treasury "Separation of Line and Energy Businesses" 9 June 1988, 1-2 ["Treasury 15"]; Treasury "Update on Reforms in the Electricity Distribution and Retailing Sectors" 2 March 1998 ["Treasury Seven"]; "Treasury Two" above n 48, 12; Treasury "Competition in the Electricity Industry" Memorandum to Senior Management Group, 17 February 1998, 1 ["Treasury Five"]; OCEP "Electricity Distribution Reforms: OCEP Briefing to Ministers" 3 September 1997, 1 ["OCEP Three"]; "OCEP Eight" above n 48, 1; and "Commerce Three" above n 48, 1. 
The main concerns were therefore threefold: the potential for monopoly rents, crosssubsidisation and restricted access. ${ }^{51}$

The point of this part is to isolate problems the ownership split could conceivably fix from those which were targeted by other means. The reason for the ownership split was simply to fix the three concerns above.

\section{GOVERNMENT REASONING}

The Government was not short on advice as to how to deal with these three issues. Reporting to it were two government departments, Treasury and the Ministry of Commerce (Commerce); an interdepartmental body, the Officials Committee on Energy Policy (OCEP); 52 and a number of private consultants. A huge volume of options, arguments, pros and cons were produced over about eight months. There are two very interesting features about this wealth of advice. The first is that it was all largely in agreement. The second is that the Government chose to ignore it.

\section{A Evidence and Analysis of Specific Policy Problems}

All of the various advisors acknowledged the potential problems of monopoly rents, cross-subsidisation and restricted access. They concluded however that these problems were largely theoretical - there were economic incentives for such behaviour, but little evidence that it was occurring. It was common ground that there had been no study of these issues and that any evidence of the three anti-competitive practices was inconclusive at best.

This last point is significant. Not only was there no specially commissioned study; but information which was available had never been analysed. A paper prepared for a Cabinet Committee noted that, although information was disclosed annually under the relevant regulations "the disclosed information is not adequately scrutinised from the regulatory perspective (the Ministry of Commerce is not currently resourced to do this work and the scrutiny from non-Government agencies appears to be limited)". ${ }^{53}$ Indeed,

51 See documents listed in above $\mathrm{n} 50$.

52 Comprising representatives from Treasury, the Prime Minister's Department, and the Ministries of Commerce and the Environment.

53 "Cabinet Committee Two" above n 3, 11. The Ministry of Commerce stated that its analysis of disclosed information "has been confined to the ranking of companies on the basis of their disclosed performance measures": "Commerce Four" above n 22, 9. 
one of Treasury's recommendations was that the reforms include funding to actually analyse disclosed information. ${ }^{54}$

Turning to the first of the three concerns, monopoly pricing was seen as the most serious problem. Even so, evidence of its practice was scarce. Treasury stated that "[i]t is unclear that monopoly pricing is more of a problem in the case of electricity than in other [vertically integrated natural monopoly] industries". 55 The term "monopoly pricing" can in fact denote two different problems: excessive profits and excessive costs. Officials did not identify any tangible evidence of excessive profits - OCEP openly stated that its main concern was the "future potential" for problems. ${ }^{56}$ Commerce compared the accounting rate of profit (ARP) of ECs for the years 1994/1995 to 1996/1997 to an estimated weighted average cost of capital (WACC) range and found that that ARPs were roughly half WACC. ${ }^{57}$ An ARP equal to WACC indicates a firm is exactly covering its costs and not earning excessive profits. ${ }^{58}$ An ARP of half WACC is exceptional. Commerce thus concluded that ECs are "on average not earning monopoly profits on their line businesses at present". .5

Commerce argued that there was a good possibility that, even if monopoly profits were not being made, monopoly costs were being charged. Commerce viewed this problem as the most significant and argued that lines businesses had potential for $\$ 40-\$ 100$ million per annum savings in efficiency gains. ${ }^{60}$ Other advisors were not so convinced. Treasury consistently highlighted the lack of evidence of any monopoly pricing in the first place. ${ }^{61}$ The OCEP concluded more modestly that without robust competition, "pressure on costs may be insufficient to achieve the Government's objectives". ${ }^{62}$

54 Treasury "Competition in the Electricity Retail and Distribution Sectors - Update" 21 October 1997, 2 ["Treasury Three"].

55 "Treasury One" above n 37, 4.

56 "OCEP Three" above n 50, 3.

57 "Commerce Four" above n 22, 10.

58 "Commerce Four" above n 22, 10.

59 "Commerce Three" above n 48, 2. For 1994/1995 the ARP median was 3.85, the WACC range 7.48.9; for 1995/1996 the ARP median was 4.79, the WACC range 8.4-9.9; for 1996/1997 the ARP median was 5.46, the WACC range 8.5-10.0. See also "Commerce Four" above n 22, 11; "OCEP Five" above $n 35,5$.

60 "Commerce Three" above n 48, 1-2.

61 See "Treasury One" above n 37, 4; "Treasury Three" above n 54, 13.

62 "OCEP Five" above n 35, 4 (emphasis added). 
The evidence of cross-subsidisation was extremely weak. Commerce acknowledged that its examination of cost allocations between lines and retail activities indicated that: 63

...the majority of companies seem to be allocating a greater than expected proportion of their costs to their retail activities. This is the opposite to what would be expected if companies were attempting to cross-subsidise their retail or generation activities from their natural monopoly distribution activities.

Commerce noted that analysis of retail margins for different customer groups of individual companies "provides only very isolated evidence of cross-subsidies". 64 OCEP stated that is "not possible to conclude whether cross-subsidisation is occurring". 65 Treasury and Commerce both argued that cross-subsidies were not even consistent with profit-maximising behaviour in the long-term. ${ }^{66}$ This is because a cross-subsidy involves the injection of profits from one business to make another more competitive. Long-term overall profit is lessened.

The access problem was widely acknowledged to be minor and largely historical. ${ }^{67}$ Although Commerce opined that ECs have strong incentives to restrict access in order to retain captive customers, ${ }^{68}$ officials admitted that "there is no explicit evidence of access problems". ${ }^{69}$ A recent report had noted that "large electricity companies had moved away from restrictive access arrangements to more open access and that access pricing is "less" than the Baumol-Willig rule". ${ }^{70}$ Officials agreed that electricity access problems were less significant than those seen in telecommunications. ${ }^{71}$

63 "Commerce Three" above n 48, 3.

64 "Commerce Three" above n 48, 3.

"Cabinet Committee Two" above n 3, 11

"Treasury One" above n 37, 5; "Commerce Four" above n 22, 21.

67 "Commerce Three" above n 48, 3.

68 "Commerce Four" above n 22, 19.

69 "Treasury Two" above n 48, 13. See also "Commerce Four" above n 22, 19.

70 "Treasury One" above n 37, 4. This rule had been controversially applied by the Privy Council to the telecommunications industry. See Telecom Corporation of New Zealand Ltd $v$ Clear Communications Ltd [1995] 1 NZLR 385.

71 Cabinet Committee on Industry and the Environment "Electricity Reforms: Paper Four: Options for Electricity Distribution and Retailing" 28 November 1997, CIE (97) 195, 8 ["Cabinet Committee Four"]. 
Finally, most advisors also believed high community ownership of ECs to be a concern. In 1997, there were 22 wholly community-owned companies (20 trusts and two cooperatives) and only five investor-controlled companies out of $35 .{ }^{72}$ There were three alleged problems. The first was lack of efficiency. Community-owned companies were perceived to lack the financial discipline and accountability demanded by private shareholders. ${ }^{73}$

The second problem was a view that community companies were reluctant to merge and thus rationalise the market. The third problem was that trusts were viewed as anticompetitive. Official papers including Cabinet Minutes repeatedly noted that trustownership of retail businesses may "reduce the level of retail competition where rebates or low prices based on non-commercial rates of return are offered to customers of the trust". ${ }^{74}$ Accordingly, ECNZ's main presentation to the Government argued that ownership separation would "solve the Trust problem";75 and Treasury suggested that a potential solution to retail/distribution problems was to "ban trusts". ${ }^{76}$

\section{B Advice Tendered and Government Response}

Despite having the advantage of dissuading trusts from contestable activities, advisors overwhelmingly opposed ownership separation of lines and retail businesses. ${ }^{77}$ The advice from different quarters was remarkably consistent. All advisors saw the main industry problems as belonging to the generation sector or caused by inadequate technology - and these had been addressed by other means. ${ }^{78}$ Of the three remaining

72 See Carolyn Wylie Electricity in New Zealand (Chameleon Enterprises, Wellington, 1997).

73 Commerce believed that community-owned companies were more likely to pass monopoly costs through to consumers due to inefficiency: see "Commerce Four" above n 22, 15. Commerce and Treasury believed that trusts would take "a less rigorous approach to the economics of investment": "Cabinet Committee Four" above n 71, 6.

74 Cabinet "Electricity Reform Proposals" 15 December 1997, CAB (97) M 47/33, 4 ["Cabinet One"]; "Cabinet Committee Four" above n 71, 9.

75 "Response to Review" above n 40, 5.

76 "Treasury One" above n 37, 6.

77 Cabinet Economic Committee "Electricity Distribution and Retail Reforms" 23 March 1998, ECO (98) 31, 3 ["Cabinet Committee 11"]; Hon M Bradford "Paper 1: Electricity Distribution and Retail Reform" 20 March 1998, 10-11 (summary of officials' views of key issues) ["Paper 1"]; Tony Baldwin (Chair of OCEP) "Electricity Distribution and Retail Reform: Key Issues" 17 March 1998, 2 ["OCEP 10"]; "OCEP Eight" above n 48, 10; "Treasury Five" above n 50, 7; Treasury "Electricity Reform Package" 24 March 1998, 2 ["Treasury Nine"]; Commerce "Electricity Distribution and Retail Reform - Policy Options" 18 March 1998, 2 (of annex) ["Commerce Six"]; McKinlay Douglas Ltd "Retail Competition" September 1997, 4 ["McKinlay Douglas"].

78 See above nn 48 and 77. 
problems, monopoly rents was viewed as the only genuine concern. ${ }^{79}$ All advisors made the same two points about this problem. First, monopoly rents would not be prevented by ownership separation, as a stand-alone lines company could still charge excessive prices. ${ }^{80}$ Secondly, on the other hand, preventing monopoly rents would also prevent crosssubsidisation. ${ }^{81}$ This is because it was only the excess line profits which allowed the subsidy to be made in the first place. ${ }^{82}$ Remove the profits and you remove the subsidy.

Treasury, Commerce and the OCEP advised that the key regulatory instrument was a credible government threat of price control - the most direct means of deterring monopoly pricing. ${ }^{83}$ This threat should be supplemented by better disclosure regulations; asset valuation rules; enhanced Commerce Act penalties and funded information analysis. ${ }^{84}$ These measures, together with deemed profiling; pressure from the ECNZ "babies" and standard use-of-system agreements were viewed as sufficient to address residual access problems. ${ }^{85}$

All advisors conceded that ownership separation would effectively address crosssubsidisation and access problems (but not monopoly rents). ${ }^{86}$ However they all noted

79 "Treasury Nine" above n 77, 2; "Commerce Three" above n 48, 1; Treasury "Aide Memoire: Electricity Distribution and Retail Reform Options: Key Issues" 18 March 1998, 2 ["Treasury Eight"]; "OCEP Eight" above n 48, 1; "Cabinet Committee Four" above n 71, 4.

80 "Treasury Eight" above n 79, 1; OCEP "Draft Electricity Distribution and Retail Reform - Policy Options" 18 March 1998, 11 ["OCEP 11"]; "OCEP Three" above n 50, 2 (of summary).

81 "Treasury Nine" above n 77, 2; "Commerce Three" above n 48, 4; "Cabinet Committee Four" above n $71,4,6$.

82 "Commerce Three" above n 48, 4; "Commerce Four" above n 22, 22; Cabinet Committee on Industry and the Environment "Electricity Reforms: Paper One: Overview" 1 December 1997, CIE (97) 192,10 ["Cabinet Committee One"]; "Paper 1" above n 77, 11 (summary of officials' views of key issues).

83 Treasury "Electricity Reform Package: Distribution: Enhancing Threat of Price Control" 27 March 1998, 2 ("[a]side from s 36 of the Commerce Act...price control is the key instrument for addressing monopoly profits and costs") ["Treasury 10"]; Treasury "Cabinet Strategy Subcommittee Item on Electricity Distribution and Retail Reform" 31 March 1998, 1 and 2 ["Treasury 11"]; "Commerce Six" above n 77, 2 (of annex).

84 "Treasury Two" above n 48, 15.

85 Treasury stated "[w]e consider that the Commerce Act is generally adequate in addressing access issues, though its effectiveness could perhaps be improved through enhancement of penalties and remedies": "Treasury Three" above n 54, 8 . See also "Treasury 11" above n 83, 3; "Cabinet Committee Four" above n 71, 4-5.

86 "Treasury Nine" above n 77, 2; Treasury "Electricity Reform: Corporate Separation of Line and Energy Businesses" 3 April 1998, 2 ["Treasury 12"]; "Paper 1" above n 77, 11 (summary of officials' views of key issues); "McKinlay Douglas" above n 77, 4. 
that these two problems were among the least significant concerns in the sector. ${ }^{87}$ All were of the view that the extra benefits of total separation were outweighed by the likely costs. ${ }^{88}$

On 15 December 1997, the Government adopted the recommendations for tighter disclosure regulations; new valuation rules; government-funded information analysis and threatened intervention on profiling if the industry did not develop a system first. ${ }^{89}$ Cabinet left the options of separation and price control on the table over the new year. ${ }^{90}$

As history now shows, the Government did not take the advice against separation. The Hon M Bradford, Minister for Energy, remained unswayed by conclusions that an ownership split was unnecessary; that its costs outweighed likely benefits; and did not tackle the problem of monopoly rents. On 23 March 1998, Mr Bradford recommended an ownership split to the Cabinet Economic Committee. ${ }^{91}$ This recommendation was accepted by the Committee on 25 March 1988 and by Cabinet on 6 April 1998. ${ }^{92}$

Mr Bradford's reasoning is set out in certain papers leading up to 6 April. His thesis was that the recommended measures merely tinkered with the existing "monopolistic" system and did not show sufficient future vision. ${ }^{93}$ Mr Bradford argued that the key policy problem stemmed from integrated (natural monopoly) lines and (potentially

87 See for instance "Treasury Eight" above n 79, 1.

88 "McKinlay Douglas" above n 77, 4; "Cabinet Committee 11" above n 77, 3; "Paper 1" above n 77, 1011 (summary of officials' views of key issues); "Treasury Five" above n 50, 7; "Treasury Nine" above n 77, 2; "Treasury One" above n 37, 2; Treasury "Ministers' Meeting on Electricity Reforms" 25 November 1997, 2 ["Treasury Four"]; "OCEP Eight" above n 48, 1, 10, 11; "Commerce Six" above n 77, 2 (of annex).

89 See "Cabinet One" above n 74, 3; "Cabinet Committee Four" above n 71, 1; Cabinet Economic Committee "Electricity (Information Disclosure) Regulations: Proposed Amendments" 18 February 1998, ECO (98) M 1/3 ["Cabinet Committee Nine"]; Cabinet "Report of the Cabinet Economic Committee: Week Ended 20 February 1998" 23 February 1998, CAB (98) M 6/7B ["Cabinet Two"]); and Cabinet Economic Committee "Electricity (Information Disclosure) Regulations: Proposed Amendments" 13 February 1998, ECO (98) 1 ["Cabinet Committee Eight"]. See generally "Cabinet Committee Four" above n 71, 1.

90 See "Cabinet One" above n 74, 3-4.

91 "Cabinet Committee 11" above n 77, 2.

92 "Cabinet Committee 11" above n 77, 1; and Cabinet "Electricity Distribution and Retail Reform" 6 April 1998, CAB (98) M 12/5, 2 ["Cabinet Six"]. A proposal to allow the Commerce Commission to impose price controls within government-set parameters was adopted at the same time.

93 Hon M Bradford "Future Directions in Electricity Markets" Letter to Hon W Peters, Rt Hon WF Birch, Hon J Shipley, 23 October 1997, 1 ["Future Directions"]. 
competitive) generation and retail businesses. ${ }^{94}$ Mr Bradford viewed the two types of activities as theoretically and practically distinct. Any regulatory difficulties which stemmed from their intersection were best solved by their total separation. Objections that this step was excessive compared to the size of the problem were a result of analysis "heading in the wrong direction" and would "lead to a disaster". 95 Mr Bradford supported his argument by analogy to the 1994 split of the national grid Transpower from generator ECNZ. ${ }^{96}$

\section{RESULT}

The EIR Act was enacted on 8 July 1998. ${ }^{97}$ The Act is complex and was carefully drafted to minimise loopholes. The Act defined two types of electricity businesses: lines businesses, which convey electricity by line; ${ }^{98}$ and supply businesses, which generate and/or sell electricity. ${ }^{99}$ The main provision of the Act is section 17 which prohibits the same party being involved in both businesses. "Involved" is extremely widely defined and includes a 10 per cent overlap in control or ownership. ${ }^{100}$ Section 18 prohibits any parties involved in one type of businesses holding, in aggregate, more than 20 per cent of the control or ownership rights in the other type of business. Section 30 prohibits a party increasing their existing cross-involvements (that is, increasing their breach of sections 17 and 18).

The Act set out complex rules for complying with sections 17 and 18. Essentially there were four options:

\section{Early ownership split}

A party could chose to comply by 1 July 1999. The great advantage of doing so was a limited exemption from section 30 until this date. ${ }^{101}$ This gave a company one year to acquire new businesses before splitting up. Crucially, community-owned supply

\footnotetext{
94 "Paper 1 " above n 77, 2.

95 "Future Directions" above n 93, 1.

"Paper 1" above $\mathrm{n} 77,1,4$.

7 The Act was passed under urgency and as a confidence motion.

EIR Act, s 4 . See above $n 4$

9 EIR Act, s 5 . See above $\mathrm{n} 4$.

100 EIR Act, s 7. See also ss 8 - 10. "Involved" also includes having "material influence" over a business: s 7. For the definition of "material influence" see s 11.

101 EIR Act, s 35.
} 
businesses were permanently barred from expanding. ${ }^{102}$ Unlike other companies, they could not acquire new generation or retail assets.

\section{Delayed ownership split}

A party could choose to comply by 1 January $2004 .{ }^{103}$ The quid pro quo was no exemption from section 30 (that is, no right to expand) and an obligation of "corporate separation": placing both the lines and supply businesses in different companies which would be subject to strict "arms length" separation rules from 1 April 1999. ${ }^{104}$

\section{Mirror trust}

This only applied to trust-owned ECs. ${ }^{105}$ These trusts could, by 1 April 1999, form a "mirror trust" to hold the other business of the existing trust. ${ }^{106}$ Both trusts must have similar trust deeds and the same beneficiaries. ${ }^{107}$

\section{Widely held trust/company}

This also applied only to trusts. It allowed the trusts to keep one business, sell the other business to a company, but make the shareholders of the company the same as the beneficiaries of the trust. ${ }^{108}$

In short, the Act required ownership separation by 2004. If this was done by July 1999, expansion was allowed in the meantime. If not, expansion was prohibited and stringent corporate separation rules would apply from April 1999. Trusts were strongly encouraged to sell their supply businesses through a permanent bar on expansion.

The reaction of the electricity industry to such legislation must have surpassed the Government's wildest dreams. With one exception, every EC in New Zealand chose early

102 EIR Act, s 46. This prohibits the transfer of supply businesses to "agencies" which are in turn defined (by s 13) as entities in which interests are held by more than six people, and where those interests were "expectancies" and not freely transferable - that is, trusts.

103 EIR Act, s 27(a).

104 EIR Act, ss 24 and 25. See also the First Schedule to the Act.

105 See EIR Act, ss 38(3) and (4)

106 EIR Act, ss 37 and 38.

107 EIR Act, ss 40 and 41.

108 EIR Act, ss 20(2) and 34. 
ownership separation. ${ }^{109}$ There were several reasons for this. First, the SOE generators (Contact and the ECNZ "babies") and the major foreign-owned EC's saw an opportunity to expand and become large generator/retailers (genrets). The SOE generators were being unleashed on the retail market for the first time, so buying customers was essential. ${ }^{110}$ These large businesses thus aggressively pursued the retail and generation businesses of smaller ECs. Conversely, smaller ECs were concerned that they would be unable to compete with the new breed of genrets, especially as they would now have to buy most of their electricity from their competitors.

Thirdly, the economies of scale of a stand-alone supply business effectively restricted this option to large players. This fact was well recognised at the time. ${ }^{111}$ Fourthly, 22 of the 35 ECs were wholly community-owned which barred them from expanding their supply businesses. Mirror trusts and company/trusts were not considered fiscally viable. ${ }^{112}$ Finally, as everyone else was selling by April 1999, ${ }^{113}$ many believed that to hang on to assets after this date would not only require corporate separation costs but also risk a firesale five years later. ${ }^{114}$

The selling frenzy between July 1998 and April 1999 was both awesome and confusing. The consequences of this scramble were also perhaps lost in the confusion. The most

109 The exception was Top Energy which had started building a new generation plant, Ngawha Power Station, just before the reforms were introduced. Being a small trust, Top Energy could not afford to be a stand-alone supply business, but did not want to sell Ngawha immediately. Top Energy thus sold its retail business to Contact Energy and applied for an exemption from the EIR Act for Ngawha. When its application was refused on 10 June 1999, Top Energy reluctantly formed a mirror trust to separately hold its lines and generation businesses. See Commerce Commission Decision No. 353 (10 June 1999).

110 The SOE generators were previously prevented from retailing by directives in their Statements of Corporate Intent: see above $n 29$.

111 During debates on the EIR Act, P Hodgson, MP (Labour) stated "What is the hidden agenda? The hidden agenda is that the little energy companies that split off will not stand alone. Despite all this mirror trust stuff, they cannot stand alone...That means they will be sold. Who will buy them? The baby ECNZs will buy them...We are nationalising community assets": (19 May 1998) 568 NZPD 9155. J Fitzsimmons, MP (Alliance) stated "At the retail level the Bill is designed to destroy community-owned energy trusts...The Minister knows that at least the energy retailing half of a split trust will not be viable": (19 May 1998) 568 NZPD 9161.

112 The Court of Appeal in Cuddon v Rodley (31 March 1999) unreported, Court of Appeal, CA 67/99 noted at 4 that, on the evidence, the mirror trust option would "bring significant commercial disadvantages".

113 The date by which all options save early ownership separation had to be selected.

114 See Affidavit of Craig Stephen Rice (partner in PriceWaterHouseCoopers) 25 March 1999, para 16(a): prepared for Rodley $v$ Cuddon (29 March 1999) unreported, High Court, Blenheim Registry, CP 3/99 (See also the appeal, above n 112). 
profound was the transfer of almost all electricity supply businesses from small ECs to a new, dominant, cabal of genrets. In 1998 there were 35 integrated lines/retail (and sometimes small generation) businesses and two large generators which did not retail. Now there are six major genrets ${ }^{115}$ and 31 sole lines companies. ${ }^{116}$ The "big six" now control almost all the generation and retail businesses in New Zealand. ${ }^{117}$

With the SOE entry onto the retail market and the introduction of deemed profiling, retail competition was certainly possible. Whether it would work in practice to reduce domestic power bills is another story. In April 1999, TransAlta and First Electric both announced price rises. ${ }^{118}$ TransAlta blamed high line charges and pointed specifically to a recent pricing change by Orion, the Christchurch lines company. ${ }^{119}$ Orion reverted back $^{120}$ but TransAlta still refused to drop its prices. ${ }^{121}$ A week later, Trustpower announced price rises also. ${ }^{122}$ More quietly, substantial price rises were also announced in the provincial areas of Waitaki and King Country. ${ }^{123}$

115 These are TransAlta, Contact, Mighty River Power (including its retail subsidiary, First Electric) Trustpower, Genesis and Meridian, which together hold 97 per cent of the retail market. The other three per cent is held by the Natural Gas Corporation, King Country Energy, Todd Energy, and Fresh Start, making 10 retailers in total. Statistics from "Investment Statement" above n 3, 15 and Consumer Powerswitch Database at <http://www.consumer.org.nz/powerswitch/ contact.html> (last accessed 1 September 1999).

116 Figure obtained from the Commerce Commission, 26 August 1999.

117 There are some isolated exceptions. For example King Country, a trust-owned EC, chose to sell its lines and remain a supply business. It is now only 18 per cent trust-owned.

118 "Cheaper Power Plan in Tatters" The New Zealand Herald, Auckland, New Zealand, 7 April 1999, 1.

119 "TransAlta Customers Face Big Power Price Rise" The Dominion, Wellington, New Zealand, 7 April 1999, 1. As to Orion's pricing change, see "Firms to Pass on Power Charges" The New Zealand Herald, Auckland, New Zealand, 18 March 1999, C3.

120 "Southpower Turn Down Orion Offer" The Press, Christchurch, New Zealand, 8 April 1999, 1 (Southpower is the trading name for TransAlta's Christchurch operation).

121 "Southpower Turn Down Orion Offer" above n 120, 1. In fact United Networks, Wellington's lines company, had previously ruled out raising line charges for two years pursuant to an agreement with TransAlta: "Prices Won't Rise - United Networks" The Dominion, Wellington, New Zealand, 20 March 1999, 15.

122 "Trustpower Putting Prices Up" The Dominion, Wellington, New Zealand, 1 May 1999, 2. These were only for customers in Otago, Marlborough and Bay of Plenty.

123 Average domestic consumer prices in King Country rose 32 per cent (announced by King Country Energy on 25 April 1999): Commerce "Schedule of Domestic Electricity Prices" 26 May 1999, published at <http://www.moc.govt.nz/pubs/publications-03.html\#P880_37795> (last accessed 30 June 1999). In Waitaki prices rose 38 per cent (announced by Meridian on 19 July 1999): Waitaki Power Ltd, 23 August 1999. Both prices calculated for average medium domestic customers using $8000 \mathrm{kWh}$ per annum. 
There was a huge amount of public finger pointing by retail companies at lines companies and vice versa. It was difficult to know who to believe. It appeared that both lines and retail companies had some incentives to reduce prices. When they split, lines companies sold their metering facilities to retail companies. This reduced the asset base on which they could claim a return. ${ }^{124}$ On the other hand, the fact of competition was meant to push retail prices down.

Whoever was to blame, the publicity did not portray the EIR Act as an unqualified success. This was bad election year press. The government was stung into action. It hastily ditched the "specific thresholds regime" of price control announced in April 1998 and developed by the Commerce Commission over the previous year. This regime had been designed to create a credible, but not actual, threat of price control. It worked by ranking all lines companies according to a complex system, then placing the bottom 25 per cent under price control.

The new solution was the Commerce Act (Controlled Goods or Services) Amendment Bill, introduced on 27 May 1999. This Bill placed all lines companies, including Transpower, directly under statutory price control. ${ }^{125}$ This was a rather dramatic departure from the mantra of light-handed regulation - and from the line of argument pursued by the Minister prior to the EIR Act, that the key to lower prices lay in the correct market structure (ownership separation) not in heavy regulation. ${ }^{126}$

The Bill emerged intact from the Commerce Select Committee but then foundered due to Labour and New Zealand First respectively withdrawing their necessary support. ${ }^{127}$ Both claimed to do so over concerns over the role of retail companies in the price hikes. Labour explained their lack of support as due to uncertainty over whether, and to what extent, line companies were to blame and sought an inquiry by the Commerce

124 There are also some economies of scale: for instance United Networks laid off 80 staff after taking over lines businesses in Auckland, Wellington and Tauranga: "Lines Network to Cut 80 Jobs" The Dominion, Wellington, New Zealand, 1 April 1999, 15.

125 Commerce Act (Controlled Goods or Services) Amendment Bill 1999, cl 54B(1).

126 As recently as 25 March 1999, the Hon M Bradford emphatically confirmed "[t]he Government has specifically decided not to place all lines companies under price control. The purpose of the proposed regime - and this is unchanged from the April 1998 reform package - is to enhance the credibility of the threat of price control": "Closing Address to the MEUG Seminar" Major Electricity Users' Group Seminar, Wellington, 25 March 1999, 6.

127 Labour announced its withdrawal on 14 July 1999; New Zealand First on 2 August 1999. See generally "Clark Calls for Inquiry Into Power Price Rises" The Dominion, Wellington, New Zealand, 4 August 1999, 2; "New Zealand First Torpedoes Power Price Control Bill" The Dominion, Wellington, New Zealand, 3 August 1999, 1. 
Commission. New Zealand First had wanted the Bill extended to control retail prices as well. The Bill was withdrawn.

By September 1999, there was competition in the main urban centres but few cheaper domestic power prices on offer. ${ }^{128}$ There was scant competition outside these centres. Neither lines nor supply companies are subject to any form of price control.

\section{INTERNATIONAL COMPARISONS}

The last 12 years of New Zealand electricity reform have actually been part of a wider trend. This is the international move from a state-owned, vertically-integrated monopoly model, to one which is privately-owned, disaggregated and market-driven. ${ }^{129}$ The similarity with which a number of seemingly different countries have chosen to restructure their electricity industries is remarkable. ${ }^{130}$ Most of the New Zealand reforms since 1987 have direct counterparts overseas. This part of the article looks at international examples of the new industry paradigm and attempts to extract lessons New Zealand could learn.

\section{A Electricity Industry Models}

One factor behind the highly similar restructuring patterns is that most countries are starting from the same place. Broadly speaking, electricity industries can be divided into four types: vertical and horizontal monopoly; purchasing agency; wholesale competition; and retail competition. ${ }^{131}$

Early this century most countries adopted the monopoly model in developing a universal supply system. Here, a single state-owned entity handles generation,

128 Price trends will be discussed in more detail in below Part VI.

129 This trend is widely documented. See Sally Hunt and Graham Shuttleworth Competition and Choice in Electricity (John Wiley \& Sons Ltd, Chichester, 1996); Michael Trebilcock and Michal Gal "Market Power in Electricity Restructurings" Unpublished Paper, 25 November 1998; CD Foster Privatisation, Public Ownership and Regulation of Natural Monopoly (Blackwell, Oxford, 1992); Mark Armstrong, Simon Cowan and John Vickers Regulatory Reform: Economic Analysis and British Experience (MIT Press, Cambridge (Mass), 1994); Matthew Bishop, John Kay and Colin Mayer Privatisation and Economic Performance (Oxford University Press, Oxford, 1994); Aynsley Hellow Transforming Power: the Politics of Electricity Planning (Cambridge University Press, Cambridge, 1996).

130 See for example the United Kingdom; Victoria, New South Wales, Australian Capital Territories, South Australia and Queensland (Australia); Ontario, Alberta, Manitoba and British Columbia (Canada); Argentina; Chile; Columbia; Venezuela; Spain; Bulgaria; the Czech Republic; India; Egypt; Norway; Denmark; Finland; Sweden; Ukraine; and California, Maine, New Hampshire and Pennsylvania (United States). Some of these countries are obviously more advanced than others.

131 This division is derived from Hunt and Shuttleworth, above $\mathrm{n} 129,22$. For a recent application of this division, see Trebilcock and Gal, above n 129, 12-17. 
transmission and supply of electricity to all consumers. No competition is allowed in any area. The widespread use of this model was premised on the theory that only a large single entity could provide the required economies of scale.

Up until the late 1980s this theory was largely true. Until new technology opened the way for smaller efficient generating units, ${ }^{132}$ the optimal size of a generation plant had continued to grow to match increased demand. ${ }^{133}$ Only a very large monopoly supplier could keep building these larger structures. ${ }^{134}$ A monopoly model was also suited to the requirements of a developing supply system as it easily allowed for rural electrification, discounts to woo large industry, and socially subsidised pricing. Further, the concept of competition in electricity supply was difficult to comprehend. Competition required separating in some way the product (electricity) from the means of delivery (lines). It was not obvious how this could be done with a commodity which cannot be stored and must be instantly dispatched to meet demand.

The purchasing agency model is only a slight variant on the monopoly model. Here, independent generators are permitted, but must sell to a single buyer (the "purchasing agency"). Generators do not have direct access to transmission or distribution lines, and customers still have no choice of supplier. This has not been widely used but was introduced in the United States by the Public Utilities Regulatory Policy Act 1978 which required integrated utilities to buy from independent generators at prices equivalent to their "avoided costs".

The wholesale competition model is the first dramatic shift from an integrated monopoly. Here, competition for large customers (usually electricity distribution/retail companies or major industrial users) is permitted. Thus generators may sell direct to some, but not all, consumers. Commercial or domestic customers must still buy from their local power company. This model requires equal access to the grid and a trading mechanism to enable competition. It is thus usually supported by separation of the national grid from the dominant generator and a wholesale market.

Finally, the retail competition model permits competition for all consumers, whether industrial, commercial or domestic. Thus local integrated lines/supply businesses retain a monopoly over their lines network but not over their retail business. Some measures must be taken to ensure that the lines part of the businesses does not inhibit competition.

132 Particularly combined cycle gas turbines: see Trebilcock and Gal, above n 129, 9.

133 See Hunt and Shuttleworth, above n 129, 2. This fact was behind the large hydro and nuclear power plants built after 1960.

134 Good examples include Ontario Hydro, Electricite de France; and the United Kingdom's Central Electricity Generating Board. See Hellow, above n 129, 15. 


\section{B Features of Transition from Monopoly to Retail Competition Model}

Over the last decade, the world has seen a general transition from the monopoly model to the retail competition model. The forces behind this shift include new technology, the fact that most countries now possess the infrastructure for public supply, and a new wave of regulatory thinking. Interestingly, this transition has almost always involved a number of key steps.

The first is the unbundling of the transmission system (the national grid) from the major, usually state-owned, generator. This has usually meant placing the two into separate companies, although neutral prices reflecting transmission costs is all that is required. ${ }^{135}$ This unbundling is generally an initial step before full retail competition is introduced. In England and Wales, the vertically integrated monopoly was initially split into four parts in 1990: two fossil-powered generators, one nuclear generator; and the national grid. ${ }^{136}$ Full retail competition was introduced nine years later in May 1999.137 Unbundling was also the first step taken by Victoria, New South Wales, Queensland, Australian Capital Territories and Ontario, well before the introduction of full retail competition. ${ }^{138}$ In the United States transmission companies are now "common carriers" although retail competition is not yet on the horizon for most States. ${ }^{139}$ Norway however did everything at once - unbundling generation and transmission and permitting full retail competition from the same date. ${ }^{140}$

The second step is the introduction of competition in generation. This has almost always required the division of the major generator into a number of smaller generators, thereby removing market dominance. England and Wales initially created three generators out of the former monopoly, but as one of them generated more expensive

135 Trebilcock and Gal, above n 129, 14.

136 This occurred by virtue of the Electricity Act 1989, which began the English and Welsh reforms.

137 Office of the Electricity Regulator (OFFER) "A Review of the Development of Competition in the Designated Electricity Market" (June 1999) 3 at <http://www.open.gov.uk/offer/ index.htm> (last accessed 29 July 1999).

138 NSW unbundled its state-owned generator/national grid with the Electricity Transmission Authority Act 1995. Full retail competition was introduced on 1 July 1999. Victoria unbundled its generator/national grid with its Electricity Industry Act 1993; Queensland unbundled through the Electricity Act 1994 (and subsequent amendments); and ACT unbundled with the Electricity Supply Act 1997. Full retail competition in these three States will be available in January 2001. Ontario unbundled Ontario Hydro with the Energy Competition Act 1998 and retail competition begins in 2000 .

139 Energy Policy Act 1992. Some states, such as California, have introduced retail competition.

140 Energy Act 1990. 
nuclear power, this created a virtual duopoly in market terms. This decision caused significant problems and has led to a substantial rethink of the generation market. ${ }^{141}$ Other regions learnt from this mistake and split their state-owned generator into more pieces - notably Victoria which split into five. ${ }^{142}$ Ontario's recent reforms required Ontario Hydro to sell down its generation capacity to 35 per cent over time. ${ }^{143}$

The third is creating a wholesale market for trading electricity (usually a spot market and in time a secondary futures market in hedge contracts). ${ }^{144}$ As with the unbundling of generation and transmission, this has usually been an initial step. In England and Wales, the wholesale market commenced in 1990, the same year as the initial reforms. Norway's power pool was set up in 1991, one year after the initial reforms and has since expanded to include Sweden, Finland and Denmark. ${ }^{145}$ In Victoria, Queensland and New South Wales the wholesale market was also created by the statutes implementing the original reforms. ${ }^{146}$ The fall in electricity prices in Victoria has been widely attributed to a successful power pool. ${ }^{147}$ A National Electricity Market began operating in Australia before small domestic customers from any State became contestable. ${ }^{148}$ Generation competition is perhaps the most effective way of reducing overall power prices. ${ }^{149}$

141 Due to a relatively dysfunctional spot market, the United Kingdom regulator has recently suggested that the market be abandoned in favour of a futures market in hedge contracts (as to the terminology, see nn 31 and 33): OFFER "A Review of Electricity Trading Arrangements: Proposals" (July 1998). This recommendation was accepted by the Government: White Paper on Energy Policy (8 October 1998).

142 See Energy Projects Division (Victoria) Victoria's Electricity Supply Industry, Toward 2000 (June 1997) 15 at <http:/ / www.energy.dtf.vic.gov.au> (last accessed 20 August 1999).

143 See the Energy Competition Act 1998 and generally the Ontario Energy Board (the regulator) website: <http:/ / www.oeb.gov.on.ca> (last accessed 25 August 1999).

144 For the definition of a hedge contract see above $\mathrm{n} 33$.

145 Sweden was granted equal access in 1996; Finland in 1997 and Denmark in 1998. See Nordic Power Exchange (NordPool) 1997 Annual Report, 1 (this is assuming that the 1998 plan to include Denmark was successful) at <http://193.69.80.130/eng97/> (last accessed 26 July 1999).

146 For Victoria see Electricity Industry Act 1993; for Queensland see the Electricity Act 1994 and for NSW see Electricity Supply Act 1995.

147 Energy Projects Division (Victoria), above n 142, 61.

148 The market has been running since 13 December 1998 and consists of NSW, Victoria, Queensland, South Australia and the ACT: See Australian Competition and Consumer Commission (ACCC) "What's Happening in the Electricity Industry" ACCC Update, June 1999, 8 and the National Electricity Market Management Company website <www.nemmco.com.au> (last accessed 11 September 1999).

149 Trebilcock and Gal, above n 129, 13. The generation part of an electricity bill accounts for around 45 per cent of the total cost to the customer: see above $n 41$. 
The fourth step is establishing a number of new positions to manage the new system. A dispatcher is required to organise the physical dispatch of electricity to meet demand and is in charge of security of supply; a transmission provider is required to set the terms of access to the grid and collect revenue; and a market operator is needed to run the trading markets and settle imbalances between contracted and actual power flows. These positions can be combined and are logically independent from the actual owner of the grid. ${ }^{150}$ For instance, the Australian National Electricity Market Management Company (NEMMCO) is both the dispatcher and market operator; but the national grids are still owned by the State grid companies. A complex agreement determines transmission terms. ${ }^{151}$ Again in Norway, the international power pool is regulated by a specialist company NordPool, while the grid remains publicly owned.

The fifth step has usually been to inject corporate ethos into retail/distribution entities. This has often been done by forcing them to become legal companies. For instance all parts of the New South Wales and Queensland electricity system are state-owned corporations; Norway has corporatised its supply companies; and Ontario supply companies must incorporate by 2002. This result has also, but only in some cases, been effected by privatisation. The Victorian and United Kingdom systems are now totally privately owned. There is currently debate over whether New South Wales' assets should be privatised. ${ }^{152}$

The sixth step is the introduction of retail competition for all consumers, usually gradually after giving generation competition time to become established. This has mostly been accompanied by some form of profiling as, without it, the costs of data reconciliation can effectively prevent competition for small customers. In Norway, for instance, high switching costs and the late introduction of profiling meant that the level of retail competition only rose to 1.0 per cent in 1997, seven years after the initial reforms. ${ }^{153}$ The

150 Although in practice the grid owner tends to be the dispatcher and the transmission provider: see for instance the United Kingdom National Grid Company.

151 The National Electricity Code.

152 See Electricity Supply Association of Australia Ltd "The Electricity Privatisation Debate" Media Statement, 25 March 1999 at <http://www.esaa.com.au/> (last accessed 20 June 1999). Privatisation was recommended in August 1997 by the NSW Committee of Inquiry into the Sale of Electricity Assets but did not get political support: see "Carr Dumps Electricity Sell-Off Plan" Sydney Morning Herald, Sydney, Australia, 18 August 1998 at <http://www.smh.com.au/ news/9808/18/pageone / pageone1.html> (last accessed 20 June 1999).

153 International Energy Agency Energy Policies of IEA Countries: Norway - 1997 Review (October 1997) Table 2, 8 at <http://www.iea.org/pubs/reviews/files> (last accessed 8 July 1999); OFFER "Review of Trading Arrangements: Background Paper 2 - Electricity Trading Arrangements in Other Countries" (February 1998) para 7.29, figure 5 ["Trading - Other Countries"]. 
United Kingdom has introduced profiling at the same time as opening all customers to retail competition. ${ }^{154}$ Most Australian States expect full retail competition by January 2001.

\section{How New Zealand Compares}

\section{Similarities}

New Zealand has introduced all of these steps, although not in this order. The timing of the New Zealand reforms appears to provide an insight into why results have been slow to arrive.

Until 1987, New Zealand had a variant of the monopoly model: the Crown owned the national grid and held a statutory monopoly on generation; ${ }^{155}$ local ESAs held area franchises and were obliged to buy from the Crown. Thus although many entities were involved, the effect was still monopolistic. ${ }^{156}$

The Government relinquished its generation monopoly in 1987. Independent generators could sell to any ESA. This seems consistent with the wholesale competition model. However this model did not really get started. The basic steps: unbundling transmission and generation; splitting the dominant generator and creating a wholesale market were introduced very late. From 1987 to 1994 ECNZ continued to own the national grid (through a subsidiary). ECNZ also retained a practical monopoly on generation until 1996 when Contact was split and a wholesale market was created. ${ }^{157}$ At this point ECNZ simply became the dominant generator. It could be fairly argued that genuine generation competition in New Zealand has only been possible since the 1998 ECNZ split.

Counter to overseas examples, corporatisation was required by 1993 and full retail competition allowed in 1994, both years before wholesale competition had even begun. ${ }^{158}$ Even with a wholesale market, domestic retail competition did not develop until deemed profiling was introduced on April 1999. Profiling or some other low-cost switching system was considered crucial in Norway and England and Wales to facilitate low-margin domestic retail competition.

154 March 1999. See "Metering and Profiling" above n 43, 27.

155 Electricity Act 1968, ss 25 and 26.

156 Electricity Act 1968, s 20.

157 The market was established by the industry. SOE Transpower is the dispatcher and transmission provider; the privately-owned Electricity Market Company is the market operator.

158 Competition for domestic customers was possible from 1 April 1993; commercial and industrial customers one year later. 
In other words, in both the generation and retail sectors, New Zealand allowed competition in theory years before providing the mechanisms for it to occur in practice. The relevant steps all occurred, but not in a logical order.

\section{Differences}

Aside from questions of timing, the New Zealand reforms have differed from their international counterparts in two crucial respects. The first is that all international reforms have involved an important seventh step: the establishment of an industry-specific regulator. The second is that none of the overseas reforms have required an ownership split of integrated line and supply companies.

It is widely acknowledged elsewhere in the world that opening up public electricity supply to competition must be done with safeguards for consumers. To ensure this, regulators were appointed with authority to control at least the natural monopoly parts of the industry. This step has accompanied reforms in England and Wales, Victoria, Queensland, New South Wales, Ontario and Norway.

Such regulators have often been the key to ensuring that domestic consumers benefit from the restructuring. For example, in England and Wales, domestic prices fell by 11 per cent in real terms between 1989 and $1996^{159}$ and another 10 per cent between 1997 and 1999. ${ }^{160}$ This was before domestic customers became contestable and despite an unsuccessful duopolistic spot market. These savings came largely from the price controls placed on line and supply charges since the beginning of the reforms. ${ }^{161}$ Another example is Victoria where prices for non-contestable domestic customers fell nine per cent in real terms since 1996 and are projected to fall another 13 per cent by December 2000. ${ }^{162}$ This has largely been due to the transmission price controls. ${ }^{163}$ The Queensland regulator was

159 United Kingdom Electricity Association "The United Kingdom Electricity System" (1996) at <http://www.electricity.org.uk> 14 (last accessed 21 July 1999).

160 OFFER "A Review of the Development of Competition in the Designated Electricity Market" (June 1999) 16 ["Designated Electricity Market"]. See also OFFER "A Review of Domestic and Small Business Supply Price Regulation: A Consultation Document" (June 1999) 28 ["Domestic and Small Business Supply Regulation"].

161 The method used by the regulator in England and Wales is the RPI-x method contemplated in the now abandoned Commerce (Controlled Goods or Services) Amendment Bill 1999, cl 70(4).

162 Energy Projects Division (Victoria), above n 142, 61.

163 See the Electricity Industry Supply Tariff Order (20 June 1995) made pursuant to s 158A of the Electricity Industry Act 1993. 
given new powers in 1998 and the New South Wales regulator has recently ordered a new inquiry into price controls for network and franchise customer charges. ${ }^{164}$

However, regulation is not simply about controlling prices. It is also about ensuring wider minimum standards. These can include social goals - such as guaranteed supply for the chronically sick and elderly; environmental goals - such as use of a certain amount of renewable energy; and service goals - such as agreed disconnection procedures and a required range of payment options. These types of consumer safeguards have routinely been incorporated into overseas licenses required to distribute or retail electricity. ${ }^{165} \mathrm{New}$ Zealand not only has no regulator but, since the Electricity Act 1992, licenses are not required for any public electricity activity.

Moreover, other countries have adopted a pragmatic approach to the advent of competition, protecting vulnerable customers from its harsher effects. For instance, while competition is now available to all consumers in England and Wales, supply (as well as lines) prices for small domestic customers remain controlled until 2000. This is because the Director General of Electricity Supply (DGES) recognises that competition in theory does not necessarily protect customers. ${ }^{166}$ Until it proves itself sufficiently robust to do so, customers will be protected by regulation. This will also be the position after full retail competition is introduced in Queensland. ${ }^{167}$ In Victoria, transmission charges are calculated with a cross-subsidy in favour of rural customers to be phased out over 25

164 For Queensland, see Queensland Electricity Regulation Unit "Regulation Position Paper" (September 1997) at <http://www.dme.qld.gov.au/energy/eru/industry/reguaril.pdf> (last accessed 11 September 1999) and the corresponding amendments to the Electricity Act 1994. In NSW, the inquiry was announced by the regulator on 21 August 1999: see <http:/ / ipart.nsw.gov.au/adverts/Elect210899.htm> (last accessed 11 September 1999).

165 These are required in England and Wales, Norway, Victoria, NSW, ACT and Ontario. See generally "Designated Electricity Market" above n 160, 9-10; "Trading - Other Countries" above n 153, para 3.5; Energy Projects Division (Victoria), above n 142, 71; ACT "Licences" at <http://www.act.gov.au/electricity/> (last accessed 23 August 1999); Ontario Energy Board "Advisory Report on License Requirements for the Marketing of Natural Gas and Electricity" (6 October 1998).

166 "Domestic and Small Business Supply Regulation" above n 160, 34.

167 Queensland Electricity Regulation Unit, above n 164, 19. 
years. ${ }^{168}$ In Norway, one of the aims of the reforms was to level different prices out, not move to a market-based user-pays system. ${ }^{169}$

New Zealand has an ability to introduce price caps for line charges to rural customers under the EIR Act ${ }^{170}$ and did attempt to bring in price control for lines companies generally in 1999. However two observations can be made. The first is that these measures were an afterthought to the New Zealand reforms and have never actually been introduced. The second is that none of these measures extended to retail companies. The potential for retail competition alone is considered a sufficient deterrent against charging excessive rates or providing inadequate service. This may not be a valid assumption for undesirable customers, such as low income families, rural users and pensioners. ${ }^{171}$

The second major difference between New Zealand and the rest of the world is that only New Zealand found it necessary to require a full ownership split of distribution/retail companies. Of course, to facilitate genuine retail competition, some split between the distribution and retail functions is required. There are however three types of possible split: an accounting split, where charges, costs and profits must be produced and disclosed separately for each business; a corporate split, where the two functions must be exercised by separate but affiliated companies; and an ownership split, where the two functions must be exercised by different companies. The rest of the world has chosen either an accounting split (Queensland, Victoria, New South Wales, Norway and England and Wales until 1999) or a corporate split (Ontario and England and Wales from 2000).

The rest of the world has considered that the costs of an ownership split (transaction costs and loss of scope economies) outweigh the gains (lack of need for conduct regulation). Largely this is because of the economics of electricity supply. The real benefits of overseas reforms have come from robust generation competition and careful regulation of transmission and distribution costs. The savings available from retail competition are, by contrast, extremely small. ${ }^{172}$ Other countries have considered full

168 Tariff Order, above n 163, cl 4.6(b) and attch 7. Queensland and Ontario have similar policies on this point, see Queensland Electricity Regulation Unit, above n 164, 7; and Ontario Ministry for Trade and Development Direction for Change: Charting a Course for Competitive Electricity and Jobs in Ontario (November 1997) 9.

169 "Metering and Profiling" above n 43, 52.

170 EIR Act, s 88 .

171 In contrast, the United Kingdom regulator is closely monitoring how competition impacts on such "disadvantaged customers": "Domestic and Small Business Supply Regulation" above n 160, 37, 50.

172 Especially to domestic consumers. For the precise figures, see above n 44 . 
ownership separation to be an excessive means of fixing a small problem. After all, whatever split is chosen, the retail competition model is already in place - this step is just to make it work more smoothly.

England and Wales provides an interesting example. The Hon M Bradford prematurely cited recent United Kingdom developments as supporting the New Zealand reform path. ${ }^{173}$ This is not an accurate claim. There are major differences between the two countries. First, the split recommended in the United Kingdom was corporate, not ownership. ${ }^{174}$ The New Zealand Government was advised that, if it required a physical split, it should select a corporate one. ${ }^{175}$ The Government rejected this advice.

Secondly, the 12 English/Welsh distribution/retail companies to be affected are all very large corporations. The added costs of corporate (let alone ownership) separation are far more easily absorbed by major companies with significant customer bases. The smallest English/Welsh company still has more than three times the amount of customers of New Zealand's largest EC; and hundreds of times the amount supplied by New Zealand's smallest EC. ${ }^{176}$ Thirdly, the major regulatory tool in the England and Wales is RPI-x price control. Thus any extra costs caused by the split could be placed on the companies themselves; not on consumers. There is no comparable protection in New Zealand.

\section{ANALYSIS}

This Part critiques the New Zealand Government's decision to implement the ownership split and highlights the problems it has caused. The argument that the ownership split was bad policy is made in three stages:

173 Hon M Bradford "UK Also Moves to Power Company Ownership Separation" Media Release, 21 June 1998. This was in response to OFFER "Reviews of Public Electricity Suppliers 1998 to 2000 Separation of Businesses Consultation Paper" (May 1998) where the possibility of an ownership split was mooted.

174 The final recommendation contained in OFFER "Separation of Businesses: Proposals and Consultation" (May 1999) and was for a corporate split.

175 See "Cabinet Committee 11" above n 77, 3.

176 The smallest distribution/retail company, SWALEC, had 970,000 customers in 1998 (a year before the corporate split was mooted). The largest, Eastern, had 3,222,000. See OFFER "Reviews of Public Electricity Suppliers: 1998-2000 - Price Controls and Competition: Consultation Paper (July 1998) 7. By comparison, in 1998 the smallest New Zealand EC was Buller Electricity with 4,027 customers; and the largest was Mercury Energy with 251,155 customers: Electricity Information Disclosure Statistics (Ministry of Commerce, Wellington, November 1998). Available at <http://www.moc.govt.nz/ers/inf_disc/disclosure_1998/disclosure12.html\#P237_1519> (last accessed 24 August 1999) ["Disclosure Statistics"]. 
(1) there was insufficient and poorly researched evidence of any problems the split could solve;

(2) even if there had been such evidence, the reasoning justifying the split was logically flawed; and

(3) the split has caused significant damage to the industry.

\section{A Insufficient and Poorly Researched Evidence of Problems}

The starting point for assessing whether the split was good or bad policy has already been stated in this article. The ownership split was the most effective way of dealing with those problems it could solve. On the other hand, it was by far the most costly and traumatic way of addressing these problems. The only question is whether the benefits of a strong solution outweighed the trauma it would cause.

\section{Insufficient evidence}

Obviously a key factor in this question is the gravity of the relevant problems. It is therefore interesting that one of the most notable features of the advice received by the Government is an almost complete lack of evidence that the problems actually existed.

It will be recalled that the main problem inhibiting domestic retail competition was the transaction costs of reconciling energy flows. This problem was addressed by the introduction of deemed profiling. The remaining three problems were monopoly pricing by lines businesses; cross-subsidisation of potentially competitive activities; and incentives to restrict access.

It will also be recalled that the ownership split did not address the potential for monopoly rents, which still exists in stand-alone lines companies. The ownership split simply eliminated the other two problems. The crucial question is then, how serious were two problems it eliminated? The answer is all too apparent.

The evidence showed only "very isolated evidence of cross-subsidies". ${ }^{177}$ In fact, it appeared that on average, cross-subsidisation went backwards. Quite contrary to the theory that retail prices were kept artificially low with excess lines profits, evidence indicated that ECs were, if anything, doing the opposite. ${ }^{178}$ This is important. The only real reason for assuming cross-subsidisation to be a genuine concern was a simplified economic theory. On the facts cross-subsidisation, at the very least, did not reveal itself as a major issue.

177 "Commerce Three" above n 48, 3.

178 "Commerce Three" above n 48, 3. 
More likely, these figures show that the Government fundamentally misunderstood the real economies of running an average New Zealand electricity company.

The evidence of access problems was no better. Officials acknowledged that no "explicit evidence of access problems" could be found. ${ }^{179}$ Access rates were provided at prices "less" than the Baumol-Willig rule ${ }^{180}$ and it was widely agreed that electricity access problems were less significant than those seen in telecommunications. ${ }^{181}$ The Commerce Commission had only received only two complaints about access to lines in the last six months of 1997,182 "suggest[ing] that access may not be a major problem". ${ }^{183}$ Given that theoretical access issues arise in every integrated network/supply business, there was nothing particular to the electricity industry that cried out for attention.

\section{Crucial data ignored}

In truth, one of the key reasons for ownership separation was to encourage smaller community-owned companies to vacate the competitive retail and generation sectors. Their incentives to do so in light of the four EIR Act options have already been discussed.

There is strong evidence that the Government believed community companies to be a major cause of the retail/distribution problems. Such companies were perceived as being less efficient than investor-owned companies and more likely to pass on excess costs to consumers. ${ }^{184}$ Officials were keen to move them into the non-competitive lines business where their prices could be controlled if necessary. ${ }^{185}$ The EIR Act was drafted so as to make this result almost inevitable. ${ }^{186}$

This bias against community companies was deeply rooted in history. Put bluntly, community companies were a mistake - an unexpected outcome of ESA corporatisation. The Energy Companies Act 1992 required ESAs to incorporate and distribute shares according to an "Establishment Plan" created by the new company and approved by the government. The Government widely expected sales to private investors (or in some cases

179 "Treasury Two" above n 48, 13. See also "Commerce Four" above n 22, 19.

180 "Treasury One" above n 37, 4.

181 "Cabinet Committee Four" above n 71, 8.

182 "Treasury Two" above n 48, 13.

183 "Treasury Three" above n 54, 4.

184 See above $\mathrm{n} 73$.

185 See "OCEP Three" above n 50, 7; "Response to Review" above n 40, 5; "Treasury One" above n 37, 6.

186 See the EIR Act s 46 and the comments in Hansard cited in n 111 above. 
local councils); or share give-aways to consumers, who would then on-sell to larger investors. ${ }^{187}$ Corporatisation was clearly intended as a prelude to privatisation.

Contrary to this aim, a group of ESAs developed the innovative idea of selling their shares to a trust, which in turn would be owned by the local community. It was unclear for a number of months whether an Establishment Plan of this type would be acceptable to the Government. A key consultant's report recommended that a plan providing for 100 per cent trust ownership "should lead to outright rejection" as it was "reminiscent of the old style power boards which the Government is trying to change". ${ }^{188}$

Ultimately however, the political delicacy of this issue compelled the Government to grudgingly capitulate. ${ }^{189}$ Directly after corporatisation, there were 44 ECs, exactly half of which were wholly community-owned. ${ }^{190}$

To return to the present, the ownership split was at least partly designed to finish the job. ${ }^{191}$ The 1998 arguments revived with vigour the 1992 allegations that communityowned entities were not commercially viable. ${ }^{192}$ The government's unmasked dislike of community companies is crucially important given that in 1998, community companies comprised 22 of the 35 ECs. ${ }^{193}$

This agenda might not have been a problem if the Government's negative assertions about community companies had been true, or at least researched. The fact is that they were neither. A little simple analysis shows that the Government brusquely did away with the least profit-hungry, cheapest and most efficient ECs in the country.

187 See Office of the Minister of Energy, above n 24.

188 Wheeler Campbell Ltd "Establishment Plan Approval Criteria: Economic Issues" (November 1992) 25.

189 "'Flexibility' in Trust Ownership Accepted" The Press, Christchurch, New Zealand, 28 August 1992.

190 New Zealand Electricity Directory 1993 above n 25.

191 This point is made by J Fitzsimmons, MP (Alliance) in the debates on the EIR Act. See (19 May 1998) 568 NZPD 9161.

192 In 1992 A Neill, MP (National) Chairman of the select committee which oversaw the Energy Companies Act 1992 stated that "There is no doubt that trusts are a weaker form of ownership. History shows that trust-style ownership doesn't bring maximum efficiencies": "'Flexibility' in Trust Ownership Accepted" above n 189. See also Wheeler Campbell, above n 188, 5. These were precisely the criticisms levelled at trusts by government advisors prior to the 1998 reforms.

193 New Zealand Electricity Directory 1998, above n 7. 
The relevant statistics come from the mandatory disclosures collected by the Ministry of Commerce and cover the years 1995 to 1998 inclusive. ${ }^{194}$ A division of companies into those 100 per cent community-owned (community companies); and those otherwise owned (other companies) makes an interesting comparison. ${ }^{195}$ First, community companies were content to make much less profit than their counterparts. Their accounting rates of return on assets for the four years were 4.00, 4.62, 4.83 and 4.89 per cent respectively compared with $7.48,8.47,9.48$ and 10.29 per cent for the other companies. ${ }^{196}$ This is roughly half the return taken by other companies.

Secondly, community company prices were cheaper in each of the four years for all three classes of domestic customer (small, medium, and large). ${ }^{197}$

Thirdly, evidence indicates that community companies were more efficient. Their direct line costs (expenditure directly relating to lines per kilometre divided by system length) were at least 40 per cent less in all four years. ${ }^{198}$ Their indirect line costs per customer (that is, administrative and other expenses) were also less: $\$ 99.57, \$ 97.37, \$ 101.60$ and $\$ 90.14$ respectively compared with $\$ 131.52, \$ 121.29, \$ 115.00$ and $\$ 94.47 .{ }^{199}$ All of this is remarkable given that community-owned companies were all provincial and often supplied hard to reach rural areas with high distribution costs and few customers. The opposite would have been expected. The community companies' load factor (how efficiently they use their lines) and lines loss ratio were marginally worse, but consistent with providing long-range low-density rural service. ${ }^{200}$ However, despite the difficult

194 "Disclosure Statistics" above n 176. Statistics disclosed pursuant to the Electricity (Information Disclosure) Regulations 1994. The author thanks Josh Kalderimis for his help in compiling the relevant statistics.

195 The methodology used for this comparison is detailed in Appendix One, and the statistics are contained in Appendix Two. It should be noted that Mercury Energy is counted as another company on the grounds set out in Appendix One.

196 The accounting return on equity was very similar. The accounting rate of profit for both groups also shows that community companies made less far profit. However the 1997 and 1998 ARP means are distorted by ODV re-valuations of line businesses. For instance Mercury Energy's valuation in 1996 made the other companies' mean ARP leap from 5.83 in 1996 to 10.90 in 1997. Eastland Electricity's revaluation made the community companies' mean ARP leap from 4.67 in 1997 to 13.92 in 1998. See Appendix Two, Tables 1-3.

197 See Appendix Two, Table 4.

198 See Appendix Two, Table 5.

199 See Appendix Two, Table 6.

200 See Appendix Two, Tables 7 and 8. Statistics only for 1997 and 1998. 
terrain, community companies had far less overall interruptions; and less faults per 100 kilometres of line in each year. ${ }^{201}$

These statistics contradict Government assumptions that community companies were inefficient. They in fact show the opposite: low-profit; low cost to customers; and low business costs. The 1995-1997 statistics were available to the Government when the key reform decisions were made but they do not appear to have been used to evaluate community company performance. ${ }^{202}$

Overall there was a paucity of evidence indicating that the ownership split was necessary or even desirable. In fact evidence of cross-subsidisation and access problems was minimal; and evidence that community companies (which the split would turn into sole lines businesses) operated better than other companies, ignored. Intuitive ideological biases were allowed to prevail over hard facts. ${ }^{203}$

\section{B Government Reasoning Logically Flawed}

The reasoning behind the ownership split can be criticised on at least six separate grounds.

First, the ownership split was unnecessary. The reason the electricity retail industry was singled out for further reform was that, despite full competition having been permitted since 1994, there was effectively a consumption limit for contestable customers. Only industrial users enjoyed competition. However the consumption limit was explained by the cost of the technology that allowed industrial users to be contestable. Expensive time-of-use meters cancelled out the potential retail profits for most customers. Thus the problem was inadequate technology and the real reason that there is competition today is the introduction of deemed profiling. There was no evidence linking the striking fact - no retail competition - to any issues an ownership split could solve. This was the half-baked musing of an ivory-towered economist.

Secondly, the ownership split was grossly excessive for the minor and largely intuitive problems it could address (cross-subsidisation and restrictive access). New Zealand had not yet implemented a strong accounting split - legally barring cross-subsidisation and requiring each business to be financially independent. It was clearly overkill to suddenly

201 See Appendix Two, Tables 9 and 10. Statistics only for 1997 and 1998.

202 They were not referred to in any of the documents the author obtained under the Official Information Act 1982 from Treasury, Ministry of Commerce, the Cabinet Office or the OCEP. For a list, see Appendix Three.

203 In an accurate understatement, OCEP conceded that the "assessment by officials is mainly intuitive rather then empirical": "Cabinet Committee Four" above n 71, 3. 
lurch to the most extreme form of separation. And as advisors repeatedly pointed out, ownership separation was not the only answer; the Government had a host of less drastic options to choose from. ${ }^{204}$ As Labour Energy Spokesperson Pete Hogdson described it, the ownership split was "absolutely a sledgehammer to crack a nut". ${ }^{205}$

Thirdly, even following the Government's reasoning, the ownership split was the wrong policy device. Although there was little evidence of monopoly pricing, this was the problem all officials rated the next most important issue behind inadequate technology. ${ }^{206}$ Cross-subsidisation and access problems were not regarded as such significant problems, even in theory. Thus whatever measures the Government adopted should have dealt with incentives and ability to charge monopoly rents.

Astonishingly, the Government chose a course which only weakly addressed the monopoly rent problem but blew the cross-subsidisation and access problems out of the water. This was internally inconsistent. The Government tagged monopoly rents as the key remaining issue, but chose ownership separation as its key regulatory instrument. One might argue that the Government conceded this point by abandoning the threatened price control regime before it had been tried and belatedly trying to place all lines companies under actual price control in April 1999. 207

The fourth flaw is that at least one genuine problem was never even addressed. This is regulation of Transpower's transmission charges. The 1998 reforms touched every sector of the industry save transmission. In continuing to ignore this issue, the Government placed New Zealand even further behind the rest of the world which introduced transmission price controls at the very beginning of their reforms. ${ }^{208}$ Immediately after the

204 Including actual price control, better disclosure regulations and policing of them, better ODV methodology, government encouragement of industry standard use of system agreements. See generally "Treasury Two" above $\mathrm{n} 48$.

205 (19 May 1998) 568 NZPD 9155.

206 "Treasury Nine" above n 77, 2; "Commerce Three" above n 48, 1; "Treasury Eight" above n 79, 2; "OCEP Eight" above n 48, 1; "Cabinet Committee Four" above n 71, 4.

207 It was simply too late for such controversial legislation. The EIR Act itself was only passed as a confidence motion, under urgency, and with a two-week window for select committee submissions.

208 Examples include England and Wales, Queensland, Victoria, NSW, ACT, Ontario and Norway. 
1998 reforms, excessive transmission pricing complaints resulted in major litigation which ended (without remedy) in the Court of Appeal in August 1999.209

Fifthly, the ownership split precipitated a direct transfer of wealth from small communities to large newcomers. The retail release of the four SOE generators at the same time ensured that the State received a slice of the pie. Not only was this arguably unfair; it was also oddly anti-competitive. The large players could and did buy clusters of domestic customers outright. This meant that these new or expanding companies were not forced to lower their prices to a fiercely competitive level to enter the market. They simply purchased the market outright. New Zealand's six "competitive" genrets began life with plenty of customers and significant costs to recoup.

Finally, and most importantly, the ownership split removed the only form of consumer protection many domestic customers had and replaced it with nothing. This refers to the effective removal of community-owned companies from the competitive sectors. Such companies were, as the statistics show, not profit-driven, low priced and efficient. However their real benefit was their community-ownership. Quite by chance, New Zealand had stumbled onto a truly effective structure for supplying electricity to lowmargin, commercially unattractive places.

Put simply, community ownership (especially a trust whose beneficiaries were defined as power consumers) gave consumers a natural hedge against high power prices. If the EC listened to community pressure and kept prices low, the result was low prices. And indeed this was the usual state of events. However if the EC raised prices to gain profits, then the trust as shareholder could expect a bigger dividend, which was then rebated back to consumers (usually as a discount off their power bill). If the EC made money, so did the consumer. Thus an EC could not fleece its customers other than by being inefficient. And the statistics show that community companies were generally more efficient than other companies.

The Government was well aware of this structural advantage but, somehow managed to twist it into a reason why trusts should be removed. The Government decided that this feature made trusts anti-competitive. The following quote says it all:210

209 See Mercury Energy Ltd $v$ Transpower New Zealand Ltd (1998) 8 TCLR 554 (decided on 18 December 1998) and its appeal Vector Ltd (formerly Mercury Energy Ltd) v Transpower (31 August 1998) unreported, Court of Appeal, CA32/99. The Court of Appeal decided that the prime necessities doctrine (a common law basis for challenging monopoly rents) has been superseded by the Commerce Act 1980. The High Court had already found that s 36 of this Act did not prevent Transpower from charging monopoly rents and this was not challenged on appeal. See also Richard Tweedie, CEO Todd Energy "Getting a Fair Deal from Monopolies" MEUG Seminar, above n 126, 7 who identified Transpower as "Villain No. 1 [for] excessive and illogical pricing". 
Trusts which own retail businesses are able to out-compete new entrant retailers by (i) providing rebates to customers except those who switch suppliers, and/or by (ii) offering lower prices to customers because they are willing to take lower rates of return than private sector retailers. The rebates and/or lower prices offered by trust-owned EPCs may be enhanced by special tax treatment available to trusts. Trust ownership can cause less retail competition that would otherwise occur.

This argues that trust-owned companies will be able to stifle competition by returning their profits to consumers and by seeking less profit in the first place - as well as having tax advantages. In other words they are cheap. To anyone not obsessed with privatisation, this is a good thing. However to the Government, this very point counts against community companies. This argument is illogical. If investor-owned companies could not deliver lower prices to customers of community companies, why force customers to buy from them? And here is the real flaw of ownership separation. Trusts were not anticompetitive - they were super-competitive. The Government was simply biased against them.

If it were not such a tragic mistake it would be funny. But there is one last twist. Not only did the Government effectively prevent trusts from competing with newcomers, the regions supplied by community companies were never likely to get any competition at all. So community consumers faced a double whammy. There is a simple reason why. As stated, the net retail profit per customer per annum is between three per cent and six per cent of the total bill, or $\$ 50$ per annum. ${ }^{211}$ No one in the electricity industry seriously believed that there were any substantial savings to be made in the domestic retail sector. International experience backs this up - the savings have come from wholesale competition and controlled transmission and distribution charges.

This industry adage applies a fortiori to provincial and rural regions. ${ }^{212}$ Ironically, it was these areas in which community companies were based. The largest customer base supplied by a community company was only 56,$000 ; 213$ and the average was only 20,000. ${ }^{214}$ Community companies did not supply to any main centres and covered most of

210 "Cabinet Committee Four" above n 71, 9. This argument was accepted by Cabinet in "Cabinet One" above $n 74,4$.

211 See above nn 44 and 45.

212 The CEOs of Otago Power and Central Electric stated in 1999 that they did not believe rural customers will see any competition at all due to the extremely low rural margin: "Power to the People" Otago Daily Times, Dunedin, New Zealand, 7 April 1999, 23.

213 Hawkes Bay Power. Figures from the Disclosure Regulations, see above n 176.

214 Figures from the "Disclosure Statistics" above n 176. Mercury Energy is excluded from this figure on the grounds set out in Appendix One. 
the rural landscape of New Zealand. Their customers were commercially unattractive. The replacement of community companies with a promise of competition for provincial $\mathrm{New}$ Zealand was not even sound in theory, let alone in practice.

\section{Outcome}

Given the flawed reasoning behind ownership separation, the problems it has caused are not wholly surprising. These problems fall into broadly two groups: wholesale problems and retail problems.

\section{Wholesale problems}

The result of the ownership split was of course a transfer of almost all of New Zealand's retail and small generation interests from 35 locally-based companies to a cabal of six new genrets. These new genrets varied in their amount of generation capacity and customer bases but attempted to broadly match the two. This was obviously a wise business strategy as it avoided relying heavily on fluctuating wholesale prices to supply customers. It was also a strategy with the potential to warp the newly competitive wholesale market.

The market was set up in 1996 and divided participants into three classes: generators; purchasers; and traders (which represented groups of small purchasers - no longer really necessary). The wholesale price is determined every half hour by the most expensive unit of generated electricity necessary to meet demand. A premise of the market is the supply/demand curve fixed by the differing interests of the generators on the one side and the purchasers on the other. Now, however, every major generator is also a major purchaser. And there are only six major players in total.

The potential for the wholesale electricity market to come to resemble the comfortable oligopoly of the four oil wholesalers after deregulation in 1988 is ominous. Indeed a standard economics text describes a market as an oligopoly if "the number of sellers is small, but greater than one, and if strategic interactions among sellers are important". ${ }^{215}$ Where all sellers are also buyers, strategic interactions become very important. It is currently too early to tell whether competitive or merely reactive bidding will come to characterise the New Zealand market. The amount of new players has so far led to a 
general drop in wholesale prices. ${ }^{216}$ It has yet to be seen whether this will be a long term and significant trend. The point is that such vertical-integration should not have been permitted, let alone encouraged. This was a problem which so concerned the United Kingdom regulator that in 1995 it prevented the two large generators (respectively) from gaining significant shares of the retail market. ${ }^{217}$

\section{Retail problems}

The 1998 reforms have been successful in introducing domestic retail competition. This is mainly due to the introduction of deemed profiling and the retail entry of the four SOE generators.

However, competition has not yet delivered lower prices. Nationally, prices for domestic customers increased by 3.8 per cent over the quarter from March to June 1999. ${ }^{218}$ This is despite the fact that average wholesale electricity prices dropped by 1.4 per cent in the same period.

In short, the predicted $\$ 40-100$ million of efficiency savings has not materialised. ${ }^{219}$ Even in theory, the only real savings available from domestic customers were in urban centres. But urban prices have remained basically static. Immediately following the reforms, TransAlta and First Electric raised prices in Wellington, Auckland and Christchurch - TransAlta's increases were of up to 10 per cent. ${ }^{220}$ The ensuing competition has - at best - cancelled these rises. At 1 September 1999, the best offer for an average Wellington domestic consumer was a two per cent saving on his or her December 1998

216 These dropped by 2.4 per cent between June 1998 and June 1999. See Statistics New Zealand "Quarterly New Zealand Energy Statistics - June 1999 quarter" Media Release, 1 September 1999 (see annexed tables) at <http://www.stats.govt.nz/statsweb.nsf/ 52518ce3e01f62f4cc256388000c48c0?OpenView > (last accessed 8 September 1999).

217 National Power plc proposed to merge with Southern Electric plc on 2 October 1995. PowerGen plc proposed to merge with Midlands Electric plc on 18 September 1995. Both mergers were prevented by the DGES and the Secretary of State for Trade and Industry. See "Recent Developments in the UK Electricity Industry" EU \& Competition Law Newsletter (July 1996) at <http://www.lovellwhitedurrant.com/NewSite/PUBS/EU_MON/JUNE1996/EM_16.HTM> (last accessed 8 July 1999).

218 Statistics New Zealand, above n 216, see annexed tables. Interestingly, prices for commercial customers dropped 1.1 per cent in the March-June quarter (same source).

219 This figure was estimated by the Ministry of Commerce: "Commerce Three" above n 48, 1-2.

220 See "Cheaper Power Plan in Tatters" New Zealand Herald, Auckland, New Zealand, 7 April 1999, 1; "Failed Bid Raises Prices" Sunday Star Times, Auckland, New Zealand, 11 April 1999, E1. 
bill. ${ }^{221}$ Figures suggest that some companies are not genuinely competing for domestic customers outside the regions they purchased. Meridian Energy is (nationally) merely offering to match existing prices. Contact Energy's domestic prices in Wellington are five per cent higher than the most expensive alternative. ${ }^{222}$

Predictably, the areas hit hardest were provincial and rural. Competition for such customers is basically non-existent. At 1 September 1999 only one of the 21 former community-owned EC customers had a permanent alternative offer at all, and in this region the alternative offer was still four per cent higher than that enjoyed before the reforms. 223 As early as March 1999 (before the reforms truly kicked in) prices for former community customers had risen on average by just under two per cent. ${ }^{224}$ This included a 32 per cent price rise by King Country Energy, formerly the cheapest EC in New Zealand. ${ }^{225}$ Similar price rises have continued. Trustpower raised its prices in former community company areas - Otago, the Bay of Plenty and Marlborough (the latter by 16 per cent), but not in areas it had supplied before the reforms - Tauranga, Rotorua or Taupo. 226 On 19 July 1999, Meridian raised its prices in Waitaki by 38 per cent. ${ }^{227}$

221 For an average domestic consumer using $8000 \mathrm{kWh}$ per annum on a controlled hot water plan, TransAlta at 5 December 1998 would cost $\$ 950.85$ per annum. At 1 September 1999, TransAlta would cost $\$ 1059.58$ per annum; Contact $\$ 1113.39$ per annum; and First Electric $\$ 932.34$ per annum. Meridian's standing offer was simply to match existing prices. All figures include GST and were obtained direct from the companies concerned.

222 This is comparing TransAlta's Everyday Saver Plan to Contact's Driven Energy Plan - both equivalent controlled hot water plans. For the figures, see above $\mathrm{n} 221$.

223 Consumer Powerswitch Database, above $\mathrm{n}$ 115. The only former community company region to have any permanent competition at all is Marlborough. However Meridian's Marlborough prices (as the new competitor) at 1 September are still four per cent higher than those offered by Marlborough Electric in March 1999: figures provided by Marlborough Lines. (Note: on the grounds set out in Appendix One, the figure of 21 community companies excludes Mercury Energy). Meridian's offer to give consumers who switched to it during August and September 1999 a discounted subscription to Sky TV but keep power prices the same is not counted, as it was a temporary offer and it did not reduce power prices (as to the offer, see <http:/ / www.skytv.co.nz/meridian.html> (last accessed 2 September 1999)).

224 The precise figure was 1.87 per cent: Ministry of Commerce "Schedule of Domestic Electricity Prices" above $n 123$.

225 Ministry of Commerce "Schedule" above n 123. In 1997 Consumer magazine recorded King Country as offering the lowest domestic power charges: "Power to the People" 357 Consumer March 1997, 7.

226 "Trustpower Putting Prices Up" The Dominion, Wellington, New Zealand, 1 May 1999, 2.

227 Figures supplied by Waitaki Lines, 23 August 1999. 
These rises were not wholly unexpected given that community companies satisfied with a 4 per cent margin were generally being replaced by large corporations with significant debt and a desire for a commercial rate of return. These corporations have to both recoup their purchases and achieve their required profit somehow. ${ }^{228}$ All of the six large genrets made significant outlays, especially Trustpower and TransAlta, ${ }^{229}$ and Edison Mission Energy paid $\$ 1.2$ billion for a 40 per cent stake in Contact Energy. ${ }^{230}$ These outlays were widely expected to offset potential efficiency savings. ${ }^{231}$

The privatisation or nationalisation of local power companies has also eliminated the financial protection offered by community ownership. King Country Energy provides a good example of the result. In 1999 not only did King Country Energy increase its prices by 32 per cent but the King Country Power Trust sold its 100 per cent shareholding down to 10 per cent. ${ }^{232}$ The other shares were largely distributed to private investors and King Country customers. ${ }^{233}$ As with most share give-aways, many customers have sold their shares. ${ }^{234}$ These customers have thus gone from enjoying very low prices and having excess power company profits rebated as discounts off their electricity bill, to paying high prices and being wholly vulnerable to any future rises.

Of course financial benefit is not the only or even the principal benefit of community ownership. Although it was not mentioned in any of the reports prior to the EIR Act, the local power company - which had generally been around for upwards of 70 years - was a prized asset. Amid post office closures, bank relocations and a general decline in prosperity, the local EC was property that the community had fought to own in 1992 and

228 See "Power Bills May Soar Despite Reform" The Evening Post, Wellington, New Zealand, 29 March 1999, 12.

229 Both attracted personal criticism from the Hon M Bradford for paying high prices for generation assets and customers: see "Retailers Blasted Over Prices" The Dominion, Wellington, New Zealand, 1 April 1999, 15 (criticism directed at Trustpower); and "Bradford Bullish on Power Charge" New Zealand Herald, Auckland, New Zealand, 29 December 1998, C1 (this latter article discloses that TransAlta apparently paid $\$ 647$ per customer for Power New Zealand's customer base and \$1001 per customer for Southpower's).

230 This was apparently twice the price expected: "Huge Windfall From Contact Sale" The Dominion, Wellington, New Zealand, 23 March 1999, 1.

231 See comments of Jeff Williams, CEO Trustpower and industry analysts reported in "Power Bills May Soar Despite Reform" above n 228.

232 On 11 July 1999. Information provided by King Country Energy on 25 August 1999.

233 Waitomo Energy Services Customer Trust received an eight per cent shareholding.

234 Information provided by King Country Energy on 25 August 1999. 
had won. It was one of the few things Buller, for instance, needed that was still operated from Buller.

Almost every province in New Zealand is now supplied electricity by a company based thousands of kilometres away. When Central Otago experienced power failures in the bitter July 1999 winter they had to ring Trustpower in Tauranga to try to get reconnected. It is reported that many Trustpower telephonists did not know the location of some of the affected areas. The competitive alternatives to the new incumbent, where they exist, are no closer. First Electric for instance is serviced by a call centre in Melbourne.

Further, it is a sad fact that the communities which chose to sell their supply businesses were often deeply fractured by the process. Many residents thought that the EC should have held onto the local assets - especially when they included local generation plants whatever the financial consequences. Many public meetings and angry letters to local newspapers were written. Sides were taken. In one case, the protest went all the way to the Court of Appeal. ${ }^{235}$ ECs themselves spent significant amounts of money on consultants, lobbying MPs and informing their communities of the changes.

In context, the gains to be made from the ownership split would have had to have been huge to justify abruptly reversing the 1992 reforms and effectively divesting these newly created, and much valued, local companies. No such gains were to be had. Instead significant loss and fracture has been caused, especially in rural areas. This result was not necessary. Ownership separation was not responsible for the introduction of competition; this was the work of other policy devices. The split merely created a swathe of added costs which have ironically cancelled out the effects of competition for those lucky domestic customers who enjoy it.

\section{DEEPER LESSONS}

Ownership separation was an elegant solution to a theoretical problem. From a certain perspective one can see its academic appeal. After all, the retail competition model is premised on separating the delivery of electricity from the electricity itself. If these two functions need to be separated in some way, why not do the job properly and create an ideal market structure rather than having to constantly regulate to ensure fair play. New Zealand, in its commitment to light-handed regulation, was a firm proponent of "structural" regulation. Therefore, ownership separation made perfect sense.

235 See Rodley $v$ Cuddon (29 March 1999) unreported, High Court, Blenheim Registry, CP 3/99 and Cuddon v Rodley (31 March 1999) unreported, Court of Appeal, CA 67/99. 
The problem with this argument is that it is far too abstract. It could have been made about any electricity system in the world; in fact it could have been made about any commodity at all.

Although modern thinking and technology have demonstrated that electricity is a commodity which can be sold competitively in a wholesale market and then again to consumers, it is nonetheless a unique commodity. Neither modern thinking nor modern practice indicate that it can be traded effectively in the same structure that works best for, say, baked beans. And this is the difference between overseas restructuring and New Zealand deregulation.

Other restructured electricity systems appear superficially identical. Monopolies are being disaggregated, markets are being created and competition is being introduced. But there are significant differences. First, the ideology is different. Competition, although the main tool used in lowering prices, is not the only tool. The introduction of market forces has ironically led to a revival of heavy regulation to control natural monopolies. Transmission and distribution licenses, sophisticated price control systems and an intrusive independent regulator have aggressively prevented the extraction of monopoly rents. And it is from here that a significant volume of overall savings have come. New Zealand initially rejected actual price control of lines companies, and did not even consider regulating transmission charges.

Further, most other countries have been more sceptical of the wonders of competition. They are aware that a potentially competitive market can fail to deliver low prices to all consumers; just as an inefficient monopoly can do so. ${ }^{236}$ Given this fact - and the paramount importance of electricity - most overseas regions have controlled even potentially competitive businesses in some way. Thus retail licenses controlling standards are common and vertical-integration between generators and retailers has been monitored. Price controls have also been used where the benefits of competition have not proven themselves sufficient protection. In the words of John Bridgman, the United Kingdom Director-General of Fair Trading:237

...basic competition law... was primarily intended to protect small businesses against the large, not the consumer against business. But today there is a new consciousness of the vulnerability

236 The duopoly generators in England and Wales are a good example. For a paper arguing this proposition, see Trebilcock and Gal, above n 129 .

237 J Bridgman, Director-General of Fair Trading (United Kingdom) "The Appropriate Roles of the Different Regulators and Regulatory Bodies" (10 February 1997) 1 at <http:/ / www.oft.gov.uk/html/research/sp-arch/sp-utily.htm> (last accessed 29 May 1999). 
of the consumer. The awareness that regulation and competition law is there to protect the consumer from business rather than businesses from each other, has certainly come to stay.

This consciousness is a logical result of realising that competition and lower prices, while undoubtedly related, are not necessarily the same thing. In the end, there are always some customers who are not really worth competing for. In electricity supply they will be low income, provincial, or remote customers. Other countries have regulated to protect such customers from a market which is not interested in them. New Zealand has not.

The second main difference is that the rest of the world have matched their reforms more closely to the unique market concerned. Electricity supply is unique. Demand is virtually constant but the wholesale price changes on a half-hourly basis and transmission charges can vary dramatically. ${ }^{238}$ In market terms, the industry is characterised by high production and delivery costs and very low retail margins.

Treating electricity as a generic product lacks regulatory sophistication. By doing so, the Government missed three crucial points. First, genuine savings were available through regulating transmission and distribution charges. This was not done. Secondly, by contrast, retail margins comprised a small part of the overall bill. A costly upheaval to make retail competition marginally smoother was never likely to "see electricity bills come down for all New Zealanders". 239 Thirdly, community-ownership clearly protected rural customers far better than "competition" from large, profit-driven, genrets was ever going to.

The result, as is clear, were reforms which were not tailored to the New Zealand electricity industry, but were basically the application of crude ideology. Competition is the basis for electricity regulation world-wide. However, the unique problems of market failure must be also addressed. The tragedy is that New Zealand could so easily have had the best of both worlds. It could have had robust retail competition for all consumers but allowed potential competitors to include community-owned companies. The only change to the reform package would have been the absence of the ownership split. Instead the split allowed large SOE and private companies to easily acquire all New Zealand domestic consumers without having to compete against the incumbents.

The Government pushed ahead with the split in the face of a wealth of contrary advice. The striking similarity of the 1998 electricity reforms to other New Zealand reforms since 1984, such as the 1993 health reforms, suggests that the Government was trying to make

238 New Zealand has 244 differently priced transmission "nodes" over the country.

239 Hon M Bradford "Electricity Reforms - A Better Deal For Consumers" Media Release, 23 June $1998,1$. 
the facts fit the theory rather than examining the facts themselves. ${ }^{240}$ The results of the ownership split have illustrated the fallacy of this approach.

\section{CONCLUSION}

The ownership split ended an era which began early this century. This was the partnership between local communities and the State which enabled the development of New Zealand's electricity supply system.

The split also destroyed the 1992 re-invention of this concept: the community-owned company. This is unfortunate. As successful SOEs have shown, the commercial nous of a company is dictated by its management; not its ownership structure. The relevant statistics confirmed this. Until the split, it seemed that provincial communities had cracked the problem of how to keep low provincial prices in an era of high profitability and user-pays. The new solution is protection by raw market forces. Time will judge the wisdom of this change.

However other problems loom. From 1992, no supplier was required to supply any consumer; and from 2013, no lines company will be required to offer line services to any consumer. Problems will arise when supply and lines companies decide that some customers are simply too expensive to bother with. Whatever happens, it seems that with the demise of community companies, there is little option open to the Government now but to ignore such problems or deal with them by direct heavy-handed regulation.

It is hoped that future problems will be approached with sound evidence, advice which is heeded, and less ideology than the 1998 reforms. Utility reforms are not abstract theories, but real changes that crucially affect all New Zealanders and their communities. New Zealand has a right to demand that they are well thought out.

240 The health reforms were also based on separating the product (public health care) from its delivery by introducing competition among "providers" (including public hospitals and private entities) for limited funds distributed by Crown "purchasers". The reforms abolished area health boards (similar in concept to electric power boards); established four Regional Health Authorities as purchasers (but later replaced them with a single funding authority); and initially corporatised public hospitals into Crown Health Enterprises which were legal companies (this was relaxed in 1998). See generally the Health and Disability Services Act 1993 (and its 1995 and 1998 amendments); and the Health Reforms (Transitional Provisions) Act 1993. 


\section{APPENDIX ONE}

Methodology for comparing the performance of community-owned electricity companies to non community-owned electricity companies

(1) The facts about the total number of electricity companies and their ownership structures came from Carolyn Wylie New Zealand Electricity Directory (Chameleon Enterprises, Wellington) for the years 1993 -1998 (Electricity Directory).

(2) The data for the performance of these companies came from the information disclosed under the Electricity (Information Disclosure) Regulations 1994 (introduced pursuant to section 170 of the Electricity Act 1992) for the years 1995, 1996, 1997 and 1998 ("Disclosure Statistics"). This is conveniently complied in a Ministry of Commerce publication: Electricity Information Disclosure Statistics 1998 (Ministry of Commerce, Wellington, November 1998), available at <http://www.moc.govt.nz/ers/inf_disc/disclosure_1998/disclosure12.html\#P2 37_1519>.

(3) The only relevant difference between the two sources was that the Disclosure Statistics did not include two small electricity companies: Kaiapoi (leased to Mainpower); and from 1998, Citipower (when it was sold to TransAlta). These were counted as separate entities in the Electricity Directory. As the performance data came from the Disclosure Statistics, I followed this methodology.

(4) Accordingly, all calculations assume the following total number of electricity companies in New Zealand following the Energy Companies Act 1992:

$\begin{array}{ll}1993 & 45 \\ 1994 & 44 \\ 1995 & 43 \text { (without Kaiapoi) } \\ 1996 & 40 \text { (without Kaiapoi) } \\ 1997 & 38 \text { (without Kaiapoi) } \\ 1998 & 35 \text { (without Kaiapoi and Citipower) }\end{array}$

(5) For the research, companies were classified as 100 per cent community-owned (Community Companies) and other (Other Companies). The first group includes both trusts and community co-operatives provided full ownership remained in the local community or in current consumers. 
(6) The process was generally straightforward. Only three decisions need explaining. Mercury Energy Ltd (now Vector Energy Ltd) was and is 100 per cent trustowned. However it is counted as an Other Company for three reasons:

(a) Mercury's trust is short-term and it was always expected that Mercury would be privately-owned eventually;

(b) Mercury was New Zealand's largest EC and operated in New Zealand's largest metropolitan area; and

(c) Mercury was renowned for its private company ethos and focus on high investor-style profits.

In short, unlike all of the other Community Companies, Mercury was not the type of provincial or rural company the EIR Act was designed to eliminate. Mercury was excluded to meaningfully test the Government's theory that community companies were less efficient than more "commercially oriented" companies.

(7) The second decision was to include Wairoa Power as a Community Company, even though in 1997 the Wairoa Electric Power Trust sold down from a 100 per cent to a 60 per cent shareholding. Wairoa was 100 per cent trust-owned from 1993 to mid-1997.

(8) The third decision was to count The Power Company as an Other Company even though it is now 100 per cent trust-owned. This is because until 1998, the Power Company was Government-owned (the only electricity company so owned).

(9) All figures calculated (stated in Appendix Three) are the mean of the relevant statistic.

(10) The number of Other Companies changed between 1995 and 1998 due to mergers and acquisitions. What follows are lists of Community and Other companies for the four years.

Community Companies (1995, 1996, 1997 and 1998)

1. Buller Electricity

2. Central Electric

3. Central Hawkes Bay Power

4. Counties Power

5. Eastland Energy
6. Horowhenua Energy (also known as Electra)

7. Electricity Ashburton

8. Hawkes Bay Power

9. King Country Energy

10. Mainpower 
11. Marlborough Electric

12. Northpower

13. Otago Power

14. Scanpower

15. Tasman Energy

16. Top Energy

\section{Other Companies (1995)}

1. Alpine Energy

2. Bay of Plenty

3. Capital Power

4. Central Power

5. Dunedin Electricity

6. Egmont Electricity

7. Electricity Invercargill

8. Electro Power

9. Energy Direct

10. Mercury Energy

11. Citipower (also known as Nelson Electricity)

12. Power New Zealand

13. Powerco
17. Waipa Power
18. Wairoa Power
19. Waitaki Power
10. Waitomo Energy
21. Westpower

14. Rotorua Electricity

15. Southpower

16. Taranaki Energy

17. Taupo Electricity

18. Tauranga Electricity

19. The Power Company

20. Trustpower

21. Wairarapa Electricity

22. WEL Energy Group 


\section{Other Companies (1996)}

1. Alpine Energy

2. Bay of Plenty

3. Capital Power

4. Central Power

5. Dunedin Electricity

6. Egmont Electricity

7. Electricity Invercargill

8. Electro Power

9. Energy Direct

10. Mercury Energy

Other Companies (1997)

1. Alpine Energy

2. Bay of Plenty

3. Central Power

4. Dunedin Electricity

5. Egmont Electricity

6. Electricity Invercargill

7. Mercury Energy

8. Citipower (also known as Nelson Electricity)
11. Citipower (also known as Nelson Electricity)

12. Power New Zealand

13. Powerco

14. Southpower

15. Tauranga Electricity

16. The Power Company

17. Trustpower

18. Wairarapa Electricity

19. WEL Energy Group
9. Power New Zealand

10. Powerco

11. Southpower

12. Tauranga Electricity

13. The Power Company

14. TransAlta

15. Trustpower

\section{Other Companies (1998)}
1. Alpine Energy
5. Electricity Invercargill
2. Bay of Plenty
6. Mercury Energy
3. Central Power
7. Power New Zealand
4. Dunedin Electricity
8. Powerco 

9. Southpower
14. WEL Energy Group
10. The Power Company
15. Trustpower
11. TransAlta
16. Wairarapa Electricity
12. Trustpower
17. WEL Energy Group
13. Wairarapa Electricity

1995 Total (21 Community Companies +22 Other Companies $)=43$

1996 Total (21 Community Companies +19 Other Companies $)=40$

1997 Total (21 Community Companies +17 Other Companies $)=38$

1998 Total (21 Community Companies +14 Other Companies $)=35$ 


\section{APPENDIX TWO}

Tables of Statistics

\section{A Profit}

1 Accounting Return on Assets (per cent)

\begin{tabular}{|l|c|c|c|c|}
\hline & $\mathbf{1 9 9 5}$ & $\mathbf{1 9 9 6}$ & $\mathbf{1 9 9 7}$ & $\mathbf{1 9 9 8}$ \\
\hline $\begin{array}{l}\text { Community } \\
\text { Companies }\end{array}$ & 4.00 & 4.62 & 4.83 & 4.89 \\
\hline $\begin{array}{l}\text { Other } \\
\text { Companies }\end{array}$ & 7.48 & 8.47 & 9.48 & 10.29 \\
\hline
\end{tabular}

2 Accounting Return on Equity (per cent)

\begin{tabular}{|l|c|c|c|c|}
\hline & $\mathbf{1 9 9 5}$ & $\mathbf{1 9 9 6}$ & $\mathbf{1 9 9 7}$ & $\mathbf{1 9 9 8}$ \\
\hline $\begin{array}{l}\text { Community } \\
\text { Companies }\end{array}$ & 2.99 & 3.39 & 3.50 & 3.65 \\
\hline $\begin{array}{l}\text { Other } \\
\text { Companies }\end{array}$ & 5.53 & 6.18 & 6.49 & 7.40 \\
\hline
\end{tabular}

3 Accounting Rate of Profit (per cent)

\begin{tabular}{|l|c|c|c|c|}
\hline & $\mathbf{1 9 9 5}$ & $\mathbf{1 9 9 6}$ & $\mathbf{1 9 9 7}$ & $\mathbf{1 9 9 8}$ \\
\hline $\begin{array}{l}\text { Community } \\
\text { Companies }\end{array}$ & 3.06 & 4.25 & 4.67 & 13.92 \\
\hline $\begin{array}{l}\text { Other } \\
\text { Companies }\end{array}$ & 5.15 & 5.83 & 10.90 & 7.96 \\
\hline
\end{tabular}

The 1997 and 1998 means have been distorted by ODV revaluations. 
B Pricing

4 Domestic Delivered Prices (cents per Kilowatt Hour)

\begin{tabular}{|l|c|c|c|c|c|c|}
\hline & \multicolumn{3}{|c|}{1995} & \multicolumn{3}{c|}{1996} \\
\hline Size & S & M & L & S & M & L \\
\hline $\begin{array}{l}\text { Community } \\
\text { Companies }\end{array}$ & 13.65 & 11.67 & 11.01 & 13.89 & 12.00 & 11.45 \\
\hline $\begin{array}{l}\text { Other } \\
\text { Companies }\end{array}$ & 13.82 & 11.92 & 11.27 & 14.01 & 12.39 & 11.78 \\
\hline
\end{tabular}

\begin{tabular}{|l|c|c|c|c|c|c|}
\hline & \multicolumn{3}{|c|}{1997} & \multicolumn{3}{c|}{1998} \\
\hline Size & S & M & L & S & M & L \\
\hline $\begin{array}{l}\text { Community } \\
\text { Companies }\end{array}$ & 13.88 & 12.09 & 11.52 & 13.98 & 12.28 & 11.69 \\
\hline $\begin{array}{l}\text { Other } \\
\text { Companies }\end{array}$ & 14.31 & 12.76 & 12.11 & 14.46 & 12.91 & 12.24 \\
\hline
\end{tabular}

$\mathrm{S}=$ Small domestic customer, $\mathrm{M}=$ Medium domestic customer, $\mathrm{L}=$ Large domestic customer. All prices are inflation adjusted.

C Efficiency

5 Direct Line Costs per Kilometre (expenditure [in dollars] directly relating to lines divided by total system length)

\begin{tabular}{|l|c|c|c|c|}
\hline & $\mathbf{1 9 9 5}$ & $\mathbf{1 9 9 6}$ & $\mathbf{1 9 9 7}$ & $\mathbf{1 9 9 8}$ \\
\hline $\begin{array}{l}\text { Community } \\
\text { Companies }\end{array}$ & 1271.39 & 1161.86 & 1195.68 & 1147.96 \\
\hline $\begin{array}{l}\text { Other } \\
\text { Companies }\end{array}$ & 2356.51 & 2122.45 & 1884.18 & 1669.64 \\
\hline
\end{tabular}


6 Indirect Line Costs per Customer (in dollars)

\begin{tabular}{|l|c|c|c|c|}
\hline & $\mathbf{1 9 9 5}$ & $\mathbf{1 9 9 6}$ & $\mathbf{1 9 9 7}$ & $\mathbf{1 9 9 8}$ \\
\hline $\begin{array}{l}\text { Community } \\
\text { Companies }\end{array}$ & 99.57 & 97.37 & 101.60 & 90.14 \\
\hline $\begin{array}{l}\text { Other } \\
\text { Companies }\end{array}$ & 131.52 & 121.29 & 115.00 & 94.47 \\
\hline
\end{tabular}

7 Load Factor (efficient utilisation of lines)

\begin{tabular}{|l|c|c|}
\hline & $\mathbf{1 9 9 7}$ & $\mathbf{1 9 9 8}$ \\
\hline $\begin{array}{l}\text { Community } \\
\text { Companies }\end{array}$ & 60.21 & 61.23 \\
\hline $\begin{array}{l}\text { Other } \\
\text { Companies }\end{array}$ & 57.73 & 60.80 \\
\hline
\end{tabular}

Statistics only provided for 1997 and 1998.

8 Lines Loss Ratio (percentage of total electricity lost in financial year)

\begin{tabular}{|l|c|c|}
\hline & $\mathbf{1 9 9 7}$ & $\mathbf{1 9 9 8}$ \\
\hline $\begin{array}{l}\text { Community } \\
\text { Companies }\end{array}$ & 6.96 & 6.95 \\
\hline $\begin{array}{l}\text { Other } \\
\text { Companies }\end{array}$ & 5.60 & 5.81 \\
\hline
\end{tabular}

Statistics only provided for 1997 and 1998.

9 Total Number of Interruptions

\begin{tabular}{|l|c|c|}
\hline & $\mathbf{1 9 9 7}$ & $\mathbf{1 9 9 8}$ \\
\hline $\begin{array}{l}\text { Community } \\
\text { Companies }\end{array}$ & 421.14 & 383.95 \\
\hline $\begin{array}{l}\text { Other } \\
\text { Companies }\end{array}$ & 562.76 & 616.71 \\
\hline
\end{tabular}

Statistics only provided for 1997 and 1998. 
10 Number of Faults Over 100 kilometres of Line

\begin{tabular}{|l|c|c|}
\hline & $\mathbf{1 9 9 7}$ & $\mathbf{1 9 9 8}$ \\
\hline $\begin{array}{l}\text { Community } \\
\text { Companies }\end{array}$ & 11.69 & 9.83 \\
\hline $\begin{array}{l}\text { Other } \\
\text { Companies }\end{array}$ & 12.14 & 10.44 \\
\hline
\end{tabular}

Statistics only provided for 1997 and 1998.

\section{APPENDIX THREE}

\section{Government Policy Papers and Abbreviations}

Cabinet Committee Papers

(1) "Electricity Reforms: Paper 1: Overview" 1 December 1997, CIE (97) 192 ["Cabinet Committee One"].

(2) "Electricity Reforms: Paper 2: Analysis of Problems" 1 December 1997, CIE (97) 193 ["Cabinet Committee Two"].

(3) "Electricity Reforms: Paper 3: Options for Generation" 1 December 1997, CIE (97) 194 ["Cabinet Committee Three"].

(4) "Electricity Reforms: Paper 4: Options for Electricity Distribution and Retailing" 1 December 1997, CIE (97) 195 ["Cabinet Committee Four"].

(5) "Electricity Reforms: Paper 5: Implementation Issues for Generation" 1 December 1997, CIE (97) 196 ["Cabinet Committee Five"].

(6) "Electricity Reform Proposals" 2 December 1997, CIE (97) M 35/13-17 ["Cabinet Committee Six"].

(7) "Electricity Reforms" 4 December 1997, CIE (97) M 36/1-5 ["Cabinet Committee Seven"].

(8) "Electricity (Information Disclosure) Regulations: Proposed Amendments" 13 February 1998, ECO (98) 1 ["Cabinet Committee Eight"].

(9) "Electricity (Information Disclosure) Regulations: Proposed Amendments" 18 February 1998, ECO (98)M1/3 ["Cabinet Committee Nine"].

(10 "Electricity Corporation New Zealand Break-up: Implementation Issues" 23 March 1998, ECO (98) 33 ["Cabinet Committee 10"]. 
(11) "Electricity Distribution and Retail Reform" 23 March 1998, ECO (98) 31 ["Cabinet Committee 11"].

(12) "Electricity Corporation New Zealand Break-up: Structural Options" 24 March 1998, ECO (98) 32 ["Cabinet Committee 12"].

(13) "Electricity Distribution and Retail Reform" 25 March 1998, ECO (98) M 5/1 ["Cabinet Committee 13"].

(14) "Electricity Corporation New Zealand Break-up: Structural Options" 25 March 1998, ECO (98) M 5/2 ["Cabinet Committee 14"].

(15) "Electricity Corporation New Zealand Break-up: Implementation Issues" 25 March 1998, ECO (98) M 5/3 ["Cabinet Committee 15"].

(16) "ECNZ Restructuring: Appointment of Transition Team" 31 March 1998, APH (98) 31 ["Cabinet Committee 16"].

(17) "ECNZ Restructuring: Appointment of Transition Team" 6 April 1998, CAB (98) M 12/3D(1) ["Cabinet Committee 17"].

\section{Cabinet Papers}

(1) "Electricity Reform Proposals" 15 December 1997, CAB (97) M 47/33 ["Cabinet One"].

(2) "Report of the Cabinet Economic Committee: Week Ended 20 February 1998" 23 February 1998, CAB (98) M 6/7B ["Cabinet Two"].

(3) "Report of the Cabinet Economic Committee: Week Ended 27 March 1998" 30 March 1998, CAB (98) M 11/3D ["Cabinet Three"].

(4) "Electricity Corporation New Zealand Break-up: Implementation Issues" 30 March 1998, CAB (98) M11/3D(2) ["Cabinet Four"].

(5) "Electricity Distribution and Retail Reform" 30 March 1998, CAB (98) M 11/3D(1) ["Cabinet Five"].

(6) "Electricity Distribution and Retail Reform" 6 April 1998, CAB (98) M 12/5 ["Cabinet Six"].

Papers from the Officials' Committee on Energy Policy

(1) OCEP "Further Electricity Reforms: Next Steps" 5 August 1997 ["OCEP One"].

(2) OCEP "Electricity Reforms: Summary of Submissions" 29 August 1997 ["OCEP Two"].

(3) OCEP "Electricity Distribution Reforms: OCEP Briefing to Ministers" 3 September 1997 ["OCEP Three"]. 
(4) OCEP "Electricity: Distribution (Lines and Retail) Reform, 22 October 1997 ["OCEP Four"].

(5) OCEP "Electricity Distribution and Retail Sector Reform" (Briefing Paper), 24 October 1997 ["OCEP Five"].

(6) OCEP "Electricity Reforms: Options for Electricity Distribution and Retailing" 1 December 1997 ["OCEP Six"].

(7) OCEP "Proposed Timetable for Electricity Reforms" 18 December 1997 ["OCEP Seven"].

(8) OCEP "Electricity Distribution and Retail Reform: Policy Options" 18 February 1998 ["OCEP Eight"].

(9) OCEP "Electricity Generation, Distribution and Retail Reform - Follow-up Issues" 30 March 1998 ["OCEP Nine"].

(10) Tony Baldwin (Chair of OCEP) "Electricity Distribution and Retail Reform: Key Issues" 17 March 1998 ["OCEP 10"].

(11) OCEP "Draft Electricity Distribution and Retail Reform - Policy Options" 18 March 1998 ["OCEP 11"].

\section{Treasury Papers}

(1) Treasury "Regulatory Issues in the Electricity Distribution and Retail Sectors" 28 August 1997 ["Treasury One"].

(2) Treasury "Competition Issues in the Electricity Industry" Memorandum to Senior Management Group, 9 October 1997 ["Treasury Two"].

(3) Treasury "Competition in the Electricity Retail and Distribution Sectors - Update" 21 October 1997 ["Treasury Three"].

(4) Treasury "Ministers' Meeting on Electricity Reforms" 25 November 1997 ["Treasury Four"].

(5) Treasury "Competition Issues in the Electricity Industry" Memorandum to Senior Management Group, 17 February 1998 ["Treasury Five"].

(6) Treasury "Security of Supply: Response to Sir Ron Carter's Questions" 18 February 1998 ["Treasury Six"].

(7) Treasury, "Update on Reforms in the Electricity Distribution and Retailing Sectors" 2 March 1998 ["Treasury Seven"]. 
(8) Treasury "Aide Memoire: Electricity Distribution and Retail Reform Options: Key Issues" 18 March 1998 ["Treasury Eight"].

(9) Treasury "Electricity Reform Package" 24 March 1998 ["Treasury Nine"].

(10) Treasury "Electricity Reform Package: Distribution: Enhancing Threat of Price Control" 27 March 1998 ["Treasury 10"].

(11) Treasury "Cabinet Strategy Committee Item on Electricity Distribution and Retail Reform" 31 March 1998 ["Treasury 11"].

(12) Treasury "Electricity Reform: Corporate Separation of Line and Energy Businesses" 3 April 1998 ["Treasury 12"].

(13) Treasury "Cross-Ownership Rules in Electricity Reform Bill" 2 June 1998 ["Treasury 13 "].

(14) Treasury "Telecommunications Regulations - Comparison to Electricity" 5 June 1998 ["Treasury 14"].

(15) Treasury "Separation of Electricity Distribution and Energy Businesses" 9 June 1998 ["Treasury 15"].

(16) Treasury, Draft Parliamentary Question for Oral Answer, 16 June 1998 ["Treasury $16 "]$.

(17) Treasury, Letter to J Small, Director of the Centre for Research in Network Economics and Communications, 17 July 1998 ["Treasury 17"].

\section{Ministry of Commerce Papers}

(1) Commerce "Discussion Note on Metering and Profiling" 3 October 1997 ["Commerce One"].

(2) Commerce "NZIER Metering and Profiling: Competition for Small Electricity Consumers" 3 October 1997 ["Commerce Two"].

(3) Commerce "Magnitude of Regulatory Problems in Electricity Distribution and Retailing" 21 November 1997 ["Commerce Three"].

(4) Commerce "Background Material and Options for Increasing Efficiency in Electricity Distribution and Retailing" 4 December 1997 ["Commerce Four"].

(5) Commerce "Electricity Market Reform: Review of Submissions on Metering and Profiling" 23 December 1997 ["Commerce Five"].

(6) Commerce "Electricity Distribution and Reform - Policy Options" 18 March 1998 ["Commerce Six"]. 


\section{Papers by the Minister of Energy}

(1) Hon M Bradford "Energy: Key Issues" 15 October 1997 ["Energy: Key Issues"].

(2) Hon M Bradford "Future Directions in Electricity Markets" Letter to Hon W Peters, Rt Hon WF Birch, Hon Jenny Shipley, 23 October 1997 ["Future Directions"].

(3) Hon M Bradford "Paper 1: Electricity Distribution and Retail Reform" 20 March 1998 ["Paper 1"].

\section{Consultants' Reports}

(1) J Culy, NZIER "Comments on Electricity Competition and the Likely Outcomes From a Further Separation of ECNZ" November 1997 ["Culy Comments One"].

(2) J Culy, NZIER "Comments on a Compromise Two Way Split Huntly/Tongariro and the Rest" March 1998 ["Culy Comments Two"].

(3) Eden Resources Ltd "Environmental Impacts of Possible Electricity Reforms" 19 December 1997 ["Environmental Impacts"].

(4) McKinlay Douglas Limited "Retail Competition" September 1997 ["McKinlay Douglas"].

(5) NZIER "Metering and Profiling: Competition for Small Electricity Consumers" September 1997 ["Metering and Profiling"].

(6) Turner \& Murray "Competition in Electricity Generation - Options for a Further Slit of ECNZ" August 1997 ["Generation Competition"].

(7) Turner \& Murray "Security of Supply in a Competitive Electricity Market" December 1997 ["Security of Supply"].

ECNZ

(1) ECNZ "Response to Electricity Industry Review" 11 December 1997 ["Response to Review"].

\section{Government Media Releases}

(1) Hon W Peters, Rt Hon B Birch, Hon M Bradford "A Better Deal for Electricity Consumers" Media Release, 7 April 1998 ["A Better Deal for Electricity Consumers"].

(2) Hon W Peters, Hon M Bradford "Electricity Distribution and Retail Reforms" Media Release, 7 April 1998 ["Electricity Distribution and Retail Reforms"].

(3) Hon M Bradford "UK Also Moves to Power Company Ownership Separation" Media Release, 21 June 1998 ["UK Also Moves"]. 
(4) Hon M Bradford "Electricity Reforms - A Better Deal For Consumers" Media Release, 23 June 1998, 1 ["A Better Deal (Two)"].

(5) Statistics New Zealand "Quarterly New Zealand Energy Statistics - June 1999 Quarter" Media Release, 1 September 1999 ["Quarterly New Zealand Energy Statistics"].

\section{LE DÉMANTÈLEMENT DES SOCIÉTÉS PRODUCTRICES D'ÉNERGIE DANS LE CADRE DE LA REFORME DU SECTEUR DE L'ÉNERGIE ÉLECTRIQUE ENTREPRISE EN1998 EN NOUVELLE-ZÉLANDE OU LES EFFETS PERVERS DE L'IDÉOLOGIE}

En Avril 1998, le gouvernement néo-zélandais devait annoncer un certain nombre de réformes concernant le secteur énergétique et plus particulièrement les entreprises de fourniture et de distribution de courant électrique.

Le but poursuivi par le législateur était d'amplifier, au nom du libéralisme économique, le processus de privatisation déjà amorcé depuis 1987.

La réforme de 1998 tendait non seulement à mettre un terme à la situation de quasi monopole dont jouissait encore ECNZ (l'équivalent néo-zélandais de l'EDF en France) mais aussi à interdire les situations de concentration entre les mains d'une seule et même société commerciale, des activités de production, de transport et de distribution d'énergie électrique.

On devait cependant s'apercevoir que si le démantèlement du monopole de ECNZ pouvait avoir quelques raisons d'être (notamment en offrant parfois, une meilleure compétition et des prix plus attractifs pour le consommateur), le nouveau cadre juridique imposé à la profession, avait aussi un effet pervers.

Il forçait les petites compagnies (souvent locales) productrices d'électricité, à se défaire de leurs branches d'activité de vente au détail au profit de sociétés privées, ou étatiques, plus importantes, les obligeant parfois à licencier du personnel et sans pour autant qu'une baisse des prix de l'électricité ait été constatée.

L'auteur considère que le but recherché en 1998, mal adapté aux réalités de ce secteur d'activité, répondait surtout à un objectif idéologique et s'est révélé être une erreur tant sur le plan économique que social. 